\title{
Granice i podziały administracyjne Królestwa Polskiego i Rzeczypospolitej Obojga Narodów w XV-XVIII wieku*
}

\author{
Krzysztof Chłapowski \\ https://orcid.org/0000-0003-1539-4519 \\ Warszawa
}

Zarys treści: Artykuł przedstawia kwestię granic i podziałów administracyjnych Królestwa Polskiego i Rzeczypospolitej Obojga Narodów. Jest to przystosowany do wymogów czasopisma naukowego syntetyczny rozdział niezrealizowanego podręcznika pt. Geografia historyczna Polski do końca XVIII w. Autor omawia w nim definicję granicy, rodzaje granic, podziały administracji państwowej, zagadnienie wykreślania granic na mapach historycznych, podziały administracji Kościoła katolickiego, Kościołów wschodnich i kwestię granic majątkowych.

Słowa kluczowe: granica, dekanat, diecezja, podział administracyjny, powiat, spór graniczny, województwo

Granica to linia na powierzchni ziemi, która oddziela dwa sąsiadujące państwa, dwie jednostki świeckich i kościelnych podziałów administracyjnych (granice publiczne) lub posiadłości różnych właścicieli (granice prywatne).

\footnotetext{
* Redakcja informuje, że niniejszy tekst powstał jako rozdział podręcznika pt. Geografia historyczna Polski do końca XVIII w. i dlatego: 1. ma charakter wykładu, a nie publikacji zawierającej przedstawienie kwestii dyskusyjnych, próby ich rozstrzygnięcia i omówienie zagadnień szczegółowych; 2. chronologicznie objął okres od końca XIV w., co jest nawiązaniem do rozdziału poprzedzającego; 3 . zgodnie z koncepcją podręcznika miał dotyczyć nie tylko ziem należących do Królestwa Polskiego, ale też będących dawniej w jego zasięgu (jak Śląsk czy Pomorze); 4. nie miał opisywać delimitacji rozbiorowych, gdyż jest to rzeczywistość późniejsza. Ponieważ tekst ukazuje się w roczniku „Studia Geohistorica", należało go przygotować zgodnie z wymogami, którym podlega publikacja naukowa. Redakcja zdecydowała w związku z tym, że pozycje wyszczególnione w wykazie bibliograficznym powinny się znaleźć w przypisach. Ze względu na zły stan zdrowia autora nie można było jednak wykonać tej pracy całkowicie zgodnie ze sztuką, dlatego też przy niektórych stwierdzeniach w tekście brakuje odesłania do ich podstawy, a w przypisach nie ma odesłania do konkretnych stron. Konieczna była też zmiana tytułu. Wartość informacyjna tekstu i jego pierwotny charakter spowodowały, że redakcja nie ingerowała w jego zasięg terytorialny. Zapadła też w końcu decyzja, by nie dokonywać znaczących zmian redakcyjnych.
}

Abstract: The article deals with the problem of administrative borders and divisions of the Kingdom of Poland and the Polish-Lithuanian Commonwealth. It is a synthetic chapter of the unpublished textbook on the Historical geography of Poland to the end of the $18^{\text {th }}$ century, adapted to the requirements of a scientific journal. The author discusses the definition of the border, types of borders, divisions of state administration, the issue of drawing borders on historical maps, administrative divisions of the Catholic Church, and Eastern Churches as well as the issue of property borders.

Keywords: border, deanery, diocese, administrative division, district, border dispute, palatinate

Od XV do XVIII w. granice państwowe nie były wytyczane w terenie takimi znakami liniowymi jak w czasach współczesnych. Zdarzało się, że na niektórych odcinkach zaznaczano je, wbijając pale. Wyjątkowym zabytkiem jest powstały w $1545 \mathrm{r}$. murowany słup graniczny w Boguszach, gdzie zbiegały się trzy granice: Korony, Litwy i Prus Książęcych².

Tak jak w średniowieczu, w XVI i XVII w. przeszkody terenowe (góry, lasy, jeziora, bagna) były strefami oddzielającymi dwa państwa lub dwie jednostki terytorialne, użytkowanymi tylko $\mathrm{w}$ pasach sąsiadujących $\mathrm{z}$ osadnictwem. W miarę jego rozwoju takie obszary kurczyły się. W średniowieczu (i nie tylko) rzeki na ogół pełniły rolę elementu skupiającego osadnictwo, rzadko dzieląc dwa terytoria.

W. Maisel, Znaki graniczne, w: tenże, Archeologia prawna Polski, Warszawa-Poznań 1984. 
Pasy graniczne na obszarach zasiedlonych stopniowo się kurczyły, przy czym tempo tego zjawiska zależało od gospodarczej i strategicznej wartości terenu, rozwoju osadnictwa i utrwalania się administracji państwowej.

Od XIV do XVIII w. terytorium państwa polskiego, a później Rzeczypospolitej $^{2}$, ulegało zmianom, a co za tym idzie - zmieniały się jego granice. Zasadnicze zmiany trwałe to: przyłączenie Rusi Czerwonej (1340-1366), Prus Królewskich (1454-1466), skutki unii lubelskiej (1569), przyłączenia Inflant (1561), utraty znacznych obszarów na rzecz Rosji (1654-1667) i w końcu rozbiory (1772-1795).

Granice publicznych podziałów administracyjnych dzielą się na kościelne, tzn. granice jednostek administracji kościelnej: prowincji (metropolii), diecezji, archidiakonatów, dekanatów, parafii i oficjalatów, oraz świeckie, tzn. granice jednostek administracji państwowej, co w przypadku ziem polskich między XIV i XVIII w. oznaczało granice województw i powiatów, jako że powiat był najmniejszą jednostką świeckich podziałów administracyjnych.

Przebieg granic państwowych był ustalany w traktatach i umowach międzypaństwowych lub międzynarodowych. Dokładnego określenia i wyznaczenia granicy państw zgodnie z umową międzypaństwową dokonywały specjalne komisje, a ich czynności nazywano delimitacjąa ${ }^{3}$.

\footnotetext{
2 J. Natanson-Leski, Rozwój terytorialny Polski do roku 1570, Warszawa 1930; tenże, Dzieje granicy wschodniej Rzeczypospolitej, cz. 1: Granica moskiewska w epoce jagiellońskiej, Lwów 1922; tenże, Epoka Stefana Batorego w dziejach granicy wschodniej Rzeczypospolitej, Warszawa 1930; G. Labuda, Polska granica zachodnia. Tysiąc lat dziejów politycznych, Poznań 1974; G. Rhode, Die Ostgrenze Polens. Politische Entwicklung, kulturelle Bedeutung und geistige Auswirkung, Bd. 1 Im Mittelalter bis zum Jahre 1401, Köln-Graz 1955; H. Rutkowski, Granica mazowiecko-litewska między Wizną a Grodnem z 1358 r. „Studia Geohistorica”, 5, 2017, s. 140-155; K. Pacuski, Wschodnia granica Mazowsza w średniowieczu w świetle danych historycznych (X-XV w.), w: Początki chrześcijaństwa na pograniczu mazowiecko-ruskim w świetle wyników badań wybranych cmentarzysk, red. A. Buko, Warszawa 2019, s. 15-32.

${ }^{3}$ Z. Wojtkowiak, Delimitacja litewsko-kurlandzka z 1584 r., ,Lituano-Slavica Posnaniensia. Studia Historica", 3, 1989, s. 267-276; T. Jaszczott,
}

Przykłady najstarszych delimitacji międzynarodowych na ziemiach polskich to mazowiecko-krzyżacka ugoda graniczna z 1343 r. ${ }^{4}$ oraz protokół rozgraniczenia między ziemią lubelską a ziemią chełmską, który w 1359 r. na zlecenie króla Kazimierza Jagiellończyka z jednej strony oraz księcia bełskiego i chełmskiego Jerzego Narymuntowicza z drugiej sporządziła komisja pod przewodnictwem starosty lubelskiego i wojewody chełmskiego 5 .

Podstawą wykreślenia granicy na mapie są dla historyków protokoły delimitacyjne oraz dokumenty, w których konkretne osady przygraniczne występują z określeniem wskazującym ich państwową przynależność administracyjną. Jeśli brak takich źródeł, konieczne jest sięganie do map historycznych sporządzonych w odpowiednio dużej skali.

$\mathrm{Na}$ mapach powstałych w epoce przedkartometrycznej, czyli w czasach gdy ich nakreślanie nie było poprzedzane pomiarami w terenie, przebieg granic państwowych (i nie tylko) jest ogólny i bardzo niedokładny (słowem: umowny), z wyjątkiem odcinków, na których biegły rzekami. Na niektórych mapach z tego czasu, sporządzonych w odpowiedniej skali na podstawie źródeł typu statystycznego i z oznaczeniem odpowiednio gęstej siatki osadnictwa, przebieg granicy państwowej przedstawiany był w miarę dokładnie. W przypadku Polski pierwszą tego rodzaju mapą była Polonia Karola Perthéesa z 1770 r. ${ }^{6}$

Między XVI a XVIII w. sejm szereg razy powoływał komisje, które miały rozstrzygać spory graniczne między Polską (Rzecząpospolita) a sąsiadami. Chodziło

Granica pomiędzy ziemiami drohicką i liwską w świetle protokołów komisji z 1546 roku, „Rocznik Liwski”, 6, 2012/2013, s. 13-54.

${ }^{4}$ E. Kowalczyk-Heyman, Dzieje granicy mazowiecko-krzyżackiej (między Drwęcą a Pisą), Warszawa 2003; taż, Dzieje granicy mazowiecko-krzyżackiej (między Pisą a Biebrza), Warszawa 2013.

${ }^{5}$ Zbiór dokumentów małopolskich, cz. 4, wyd. I. Sułkowska-Kurasiowa, S. Kuraś, Wrocław-Warszawa-Kraków 1969, nr 961, s. 113-115.

${ }^{6}$ K. Buczek, Dzieje kartografii polskiej od XV do XVIII wieku. Zarys analityczno-krytyczny, Wrocław-Warszawa-Kraków 1963; S. Alexandrowicz, Kartografia Wielkiego Księstwa Litewskiego od XV do końca XVIII wieku, Warszawa 2012. 
o odcinki między województwami mazowieckim i podlaskim a Prusami Książęcymi, między województwami ruskim i podolskim a hospodarstwem wołoskim, między województwem wileńskim a księstwem Kurlandii, między Żmudzią a Prusami Książęcymi, między Koroną a Wielkim Księstwem Litewskim (czyli województwami podlaskim i brzeskim-litewskim, lubelskim i wołyńskim, kijowskim i mińskim), między województwami wielkopolskimi a należącym do cesarstwa Śląskiem, Brandenburgią i Księstwem Pomorskim itd. ${ }^{7}$

Gdy w pierwszej ćwierci XIV w. nastąpiło zjednoczenie kraju, pojawiło się pojęcie województwa jako jednostki terytorialnej. W sensie terytorialnym były one wtedy kontynuacją księstw z epoki rozbicia dzielnicowego, stąd tak duże zróżnicowanie pod względem powierzchni. Z czasem, gdy obszar Królestwa Polskiego się powiększał, liczba województw rosła. Były one głównymi jednostkami politycznego podziału terytorialnego kraju, służąc słabnącej administracji państwowej i samorządowi szlacheckiemu. Rozwój osadnictwa na obszarach niezasiedlonych powodował, że jeszcze w XVI w. na pewnych odcinkach granice między województwami nie były jednoznaczne. Dysproporcje między powierzchniami województw, jak również województw i ziem, były na ogół niezmienne, jeśli pominąć niewielkie przesunięcia lokalne.

Obszar księstwa halickiego, włączony do Polski po 1340 r., podzielono na trzy jednostki administrowane przez starostów: 1. Ruś lwowsko-halicką, 2. ziemie bełską i chełmską, 3. Podole. Dopiero w latach trzydziestych XV w. pojawiły się województwa ruskie i podolskie. Wcześniej, w 1388 r. król Władysław Jagiełło nadał ziemię bełską księciu mazowieckiemu

\footnotetext{
${ }^{7}$ Na temat międzypaństwowych sporów granicznych zob.: A. Wilkiewicz-Wawrzyńczyk, Spory graniczne polsko-litewskie w XV-XVII w. „Wiadomości Studium Historii Prawa Litewskiego”, 1, 1938, s. 93-201; A. Wielopolski, Polsko-pomorskie spory graniczne w latach 1536-1555, „Przegląd Zachodni”, 10, 1954, s. 64-111.
}

Siemowitowi IV. Gdy w 1462 r. wymarli bezpośredni potomkowie Siemowita, księstwo zostało inkorporowane do Korony i otrzymało status województwa. Ziemia chełmska była samodzielną jednostką administracyjną, którą włączono do województwa ruskiego w końcu XV lub na początku XVI w. Granice obu tych ziem podlegały zmianom, a kształt znany nam z późniejszych czasów przybrały dopiero w pierwszej połowie XVI w. ${ }^{8}$

W 1454 r. do Korony inkorporowane zostały obszary państwa krzyżackiego, na których wprowadzono podział na cztery województwa: chełmińskie, elbląskie, królewieckie i malborskie. W wyniku pokoju toruńskiego w 1466 r. zanikło województwo królewieckie (pozostało we władaniu Zakonu).

W 1474 r. z województwa sandomierskiego wyłączono wschodnią część, z której utworzono województwo lubelskie. Było to uwieńczenie procesu wydzielania się ziemi lubelskiej jako osobnej jednostki terytorialnej administracji państwowej'.

W latach 1462, 1476, 1495 i 1526 wraz z wymieraniem kolejnych gałęzi Piastów mazowieckich ich dzielnice włączane były do Korony i stawały się województwami: rawskim, płockim i mazowieckim.

Wielkie Księstwo Litewskie początkowo dzieliło się na księstwa i włości. W 1413 r. Władysław Jagiełło i wielki książę Witold powołali do życia województwa wileńskie i trockie, które w sensie terytorialnym były spadkobiercami księstw wileńskiego i trockiego, powstałych w latach

\footnotetext{
${ }^{8}$ 0. Halecki, Geografia polityczna ziem ruskich Polski i Litwy 1340-1569, „Sprawozdania Towarzystwa Naukowego Warszawskiego", 10, 1917, s. 5-24; P. Dąbkowski, Podział administracyjny województwa ruskiego i betskiego w XV wieku, Lwów 1939; K. Przyboś, Granice ziemi przemyskiej w czasach nowożytnych XVI-XVIII w., „Rocznik Przemyski”, 29-30 (3, 1), 1993-1994, s. 3-20; tenże, Granice ziemi sanockiej w czasach nowożytnych, „Rocznik Przemyski”, 32 (1), 1996, s. 21-30; tenże, Granice ziemi Iwowskiej (wraz z powiatem żydaczowskim), „Rocznik Przemyski”, 35 (4), 1999, s. 3-13; Z. Budzyński, Kresy południowo-wschodnie w drugiej połowie XVIII wieku, t. 2: Atlas historyczno-geograficzny, Przemyśl-Rzeszów 2006.

${ }^{9}$ K. Myśliński, Geneza i znaczenie powołania województwa lubelskiego w 1474 r., „Rocznik Lubelski”, 16, 1973, s. 9-25.
} 
1342-1345 w drodze umowy Olgierda i Kiejstuta ${ }^{10}$. Z czasem utworzone zostały województwa: kijowskie $(1471)^{11}$, połockie (1505), nowogródzkie $(1507)^{12}$, witebskie (1511) i podlaskie $(1513)^{13}$. Połockie i witebskie powstały z przekształcenia ziem połockiej i witebskiej, nowógrodzkie wyodrębniono $\mathrm{z}$ wileńskiego, a podlaskie $\mathrm{z}$ trockiego.

W latach 1565-1566 Zygmunt August przeprowadził w Wielkim Księstwie Litewskim wielką reformę administracyjną: z terytoriów wyłączonych z województwa wileńskiego powstały województwa mińskie i mścisławskie, a z terytoriów wyłączonych z trockiego i podlaskiego - województwo brzeskie-litewskie. Równocześnie powstały województwa: bracławskie, smoleńskie ${ }^{14}$ i wołyńskie ${ }^{15}$.

Żmudź, będąca w składzie Wielkiego Księstwa Litewskiego warunkowo od 1411 r., a trwale od 1422, wyróżniała się odrębnością, gdyż nie została przekształcona w województwo i miała specyficzną strukturę administracyjną. $\mathrm{Na}$ jej czele stał starosta, od XVII w. zwany generalnym, a jego kompetencje zbliżone były do

\footnotetext{
${ }^{10}$ М. Любавский, Областное деление и местное управление Литовско-русского государства во времени издания первого Литовского cmamyma, Москва 1892.

${ }^{11}$ Urzędnicy województw kijowskiego i czernihowskiego XV-XVIII wieku. Spisy, oprac. E. Janas, W. Kłaczewski, Kórnik 2002, s. 6. Tam też wcześniejsza literatura.

${ }^{12}$ H. Łowmiański, Rys historyczny województwa nowogródzkiego w jego dzisiejszych granicach (do r. 1795), Wilno 1935.

${ }^{13}$ W. Jarmolik, Powstanie województwa podlaskiego, „Białostocczyzna”, 4 (16), 1989, s. 6-9; D. Michaluk, Granice województwa podlaskiego i postrzeganie obszaru Podlasia w latach 1513-2013, w: Podlasie Nadbużańskie. 500-lecie województwa podlaskiego, red. 0. Łatyszonek, Ciechanowiec 2013, s. 169-191.

${ }^{14}$ Województwo smoleńskie w granicach Rzeczypospolitej 1611 (1618) - 1654 (1667), w: Urzędnicy Wielkiego Księstwa Litewskiego. Spisy, t. 4: Ziemia smoleńska i województwo smoleńskie XIV-XVIII w., red. A. Rachuba, oprac. H. Lulewicz, A. Rachuba, P.P. Romaniuk, Warszawa 2003, s. 12-17.

${ }^{15}$ Urzędnicy wotyńscy XIV-XVII wieku. Spisy, oprac. M. Wolski, Kórnik 2007, s. 19-20; М. Спиридонов, Закрепощение крестьянства Беларуси (XV-XVI вв.), Минск 1993; М. Крикун, Адміністративно-територіальний устрій Правобережної України в XV-XVIII cm. Кордони воєводств у світлі джерел, Київ 1993. Pewną, aczkolwiek nie w pełni przekonującą, propozycję przedstawienia granic historycznych na obszarze Białorusi zaprezentowano w: П. Казанецкі, В. Мікалаевіч, Гістарычны атлас Беларусі. Беларусь ад старажытных часоў да канца XVIII cm., Варшава-Міньск 2008.
}

wojewody. Żmudź dzieliła się na jednostki terytorialne o charakterze wojskowo-skarbowym zwane włościami, czyli ciwuństwa$\mathrm{mi}$, a z czasem także powiatami (od XVI w. było ich 29) ${ }^{16}$.

W 1569 r. zawarto w Lublinie polsko-litewską unię realną, w wyniku której powstała Rzeczpospolita Obojga Narodów ${ }^{17}$. Akt ten poprzedzony został przez inkorporację do Korony województw: podlaskiego, wołyńskiego, bracławskiego i kijowskiego, a to na skutek inicjatywy przedstawicieli tych ziem niezadowolonych z faktu zerwania rozmów o unii przez część delegacji litewskiej. Granice Korony i Wielkiego Księstwa Litewskiego uległy w ten sposób zasadniczym zmianom.

Traktat z Rosją w Jamie Zapolskim (1582) ugruntował przynależność do Rzeczypospolitej Inflant, od 1561 r. zarządzanych przez administratora królewskiego ${ }^{18}$. Zostały one podzielone na trzy prezydentury: dorpacką, parnawską i wendeńską, które w 1598 r. przemianowano na województwa. Traktat w Oliwie (1660) ostatecznie potwierdzał utratę większości Inflant na rzecz Szwecji, która nastąpiła na mocy rozejmu w Mitawie (1622), a potwierdzona została rozejmami w Starym Targu (1629) i w Sztumskiej Wsi (1635). Spowodowało to konieczność zmiany struktury administracyjnej Inflant, co nastąpiło dopiero w 1677 r., kiedy utworzono województwo inflanckie.

Z ziem zdobytych na Moskwie w latach 1609-1612, po rozejmie w Dywilinie

\footnotetext{
${ }^{16}$ G. Błaszczyk, Powiat rosieński w XVII-XVIII wieku. Ze studiów nad podziałami administracyjnymi Żmudzi, „Zapiski Historyczne”, 51 (1), 1986, s. 133-154; tenże, Powiat szawelski w XVII-XVIII wieku. Ze studiów nad podziałami administracyjno-terytorialnymi Żmudzi, „Acta Baltico-Slavica”, 19, 1990, s. 163-168; tenże, Powiat telszewski w XVII-XVIII wieku. Ze studiów nad podziałami administracyjno-terytorialnymi Żmudzi, „Acta Baltico-Slavica”, 19, 1990, s. 145-161; tenże, Ze studiów nad podziałami administracyjno-terytorialnymi Żmudzi. Powiat wieloński w XVII-XVIII wieku, „Roczniki Historyczne”, 51, 1985, s. 1-14.

${ }^{17}$ Tenże, Geografia historyczna Wielkiego Księstwa Litewskiego. Stan i perspektywy badań, wyd. 2, Poznań 2012.

${ }^{18}$ K. Mikulski, Przynależność Inflant do Rzeczypospolitej. Podziały administracyjne, w: Urzędnicy inflanccy XVI-XVIII wieku. Spisy, oprac. K. Mikulski, A. Rachuba, Kórnik 1994, s. 6-11.
} 
(1618) zarządzanych przez królewicza Władysława, w następstwie rozstrzygnięcia ich przynależności do Rzeczypospolitej na mocy pokoju w Polanowie (1634) utworzono w 1635 r. województwo czernihowskie ${ }^{19}$.

W 1768 r. z województwa kaliskiego wyodrębniono nowe województwo gnieźnieńskie, które objęło powiaty gnieźnieński i kcyński ${ }^{20}$. Była to ostatnia zmiana w składzie województw, która weszła w życie. W 1793 r. sejm dokonał wprawdzie nowego podziału Rzeczypospolitej na województwa, w którym uwzględniono realia pierwszego i drugiego rozbioru (utworzenie nowych województw chełmskiego i włodzimierskiego, zmiany granic województw lubelskiego, krakowskiego i sandomierskiego) oraz aspiracje lokalne (utworzenie nowych województw warszawskiego i ciechanowieckiego, przemianowanie powiatu brasławskiego województwa wileńskiego $\mathrm{i}$ istniejącego dopiero od $1792 \mathrm{r}$. powiatu mereckiego województwa trockiego na województwo). Ze względu na trzeci rozbiór Polski postanowienia sejmu w tej kwestii wprowadzono jednak tylko w ograniczonym zakresie.

W drugiej połowie XVI, w XVII, a także (choć w mniejszym stopniu) w XVIII w. sejm wielokrotnie powoływał komisje, które miały dokonywać rozgraniczeń między województwami, co wymownie świadczy, że przebieg granic wojewódzkich był na wielu odcinkach sporny i nieustabilizowany, a wyjaśnianie i rozstrzyganie wojewódzkich sporów granicznych było stałym elementem wewnętrznego życia Rzeczypospolitej. Uściślenia wymagały odcinki granic między województwami: ruskim, bełskim, podolskim, lubelskim, bracławskim i wołyńskim, między kijowskim i czernihowskim itd. Problemy i konflikty

\footnotetext{
${ }^{19}$ W. Godziszewski, Granica polsko-moskiewska wedle pokoju polanowskiego (wytyczona w latach 1634-1648), „Prace Komisji Atlasu Historycznego Polski", 3, 1935, s. 1-98.

${ }^{20}$ Z. Chodyła, Utworzenie i początki województwa gnieźnieńskiego (1768-1774-1776), w: Gniezno. Studia i materiaty historyczne, t. 2, red. J. Topolski i in., Warszawa-Poznań 1987, s. 5-69.
}

będące przyczynami tych uściśleń lub związane z nimi przewijają się w uchwałach sejmikowych.

W Polsce okresu XV-XVI w. termin ziemia (terra) używany był zamiennie $\mathrm{z}$ terminem województwo (palatinatus). Niektóre województwa (ruskie, rawskie, mazowieckie, płockie) dzieliły się jednak na ziemie. Istniały też ziemie będące osobnymi jednostkami terytorialnymi (dobrzyńska, wieluńska, wschowska), z sąsiednimi województwami związanymi niekiedy luźno (dobrzyńska, wieluńska). Powstanie ziemi wschowskiej było następstwem konfliktów z księstwem głogowskim, a ziemia dobrzyńska (początkowo część Mazowsza) po okresach przynależności do Krzyżaków (1329-1343, 1392-1405, 1409-1410) stała się osobną jednostką terytorialną.

Najmniejszą jednostkę podziału terytorialnego Korony Polskiej, a później Rzeczypospolitej, stanowiły powiaty. Ich geneza i funkcje były i są przedmiotem sporu $^{21}$. Łacińskie słowo districtus pojawiło się już w XIII w. i początkowo oznaczało okolicę, okręg, a w XIV w. - okręg z centrum w mieście, w odróżnieniu od okręgu kasztelańskiego, którego centrum był gród kasztelański. W XIV w. okręgi grodowe nie pełniły już dawnej roli elementu administracji władzy centralnej i obrony kraju. Immunitety sądowe i ekonomiczne ograniczały znaczenie kasztelanów, a funkcje grodów jako centrów obronnych przejmowały murowane zamki i miasta. Organizacja kasztelańska zaczęła zanikać, a urząd kasztelana stawał się szczeblem w hierarchii członków rady królewskiej, a później senatu. Równocześnie wprowadzony został urząd starosty jako przedstawiciela władzy centralnej (królewskiej) o uprawnieniach również sądowych, a także zarządzającego dobrami królewskimi. Władza starostów grodowych jako przedstawicieli króla

\footnotetext{
${ }^{21}$ A. Gąsiorowski, Powiat w Wielkopolsce XIV-XVI wieku. Z zagadnień zarządu terytorialnego i podziatów Polski późnośredniowiecznej, Poznań 1965; J. Bardach, Powiat w Polsce średniowiecznej, „Czasopismo Prawno-Historyczne", 19 (2), 1967, s. 135-155.
} 
była stopniowo ograniczana, a ich kompetencje redukowane na rzecz samorządu szlacheckiego.

W drugiej połowie XIV w. powstały sądy ziemskie (początkowo złożone z osób mianowanych przez władcę), które zmieniały się w samorządowe sądy szlacheckie. Polski termin powiat (po łacinie oddawany jako districtus) zaczął oznaczać okręg podlegający takiemu sądowi, zwłaszcza od 1454 r., kiedy to resztki sądowych uprawnień kasztelanów przeszły do sądów ziemskich ${ }^{22}$.

Wprawdzie podstawą organizacji sądownictwa szlacheckiego była ziemia, a nie powiat (stąd nazwa sąd ziemski), ale sesje sądów (tzw. roczki) odbywały się w siedzibach mniejszych okręgów, czyli powiatów. Właściciele dóbr leżących w powiecie mogli być pozywani do sądu w tej właśnie miejscowości.

Do powiatu sądowego należały dobra, a nie ich właściciele, dlatego przynależność do powiatu sądowego opierała się na posiadaniu dóbr (i wynikającego z tego związku grupy ludzkiej). Dotyczyło to jedynie szlachty. Mieszkańcy dóbr należących do instytucji kościelnych podlegali jurysdykcji sądów kościelnych, a należących do dóbr królewskich - jurysdykcji wójtowskiej, starosty grodowego (w sprawach kryminalnych), a w drugiej instancji - sądowi referendarskiemu. Urzędy ziemskich urzędników sądowych stawały się stopniowo terytorialne. Należy zaznaczyć, że ze względów praktycznych położenie wsi królewskich czy duchownych określano, podając nazwę powiatu sądowego, na terenie którego leżały.

Powiaty ze względu na swą genezę nie zastąpiły okręgów grodowych. Administracja państwowa najniższego szczebla przestała istnieć, a jej namiastką na szczeblu regionalnym były uprawnienia wojewodów.

$\mathrm{Na}$ ziemiach ruskich powiat zastąpił dawną wołost i dlatego do połowy XVI w.

\footnotetext{
${ }^{22}$ J.A. Gierowski, Szlachecki samorząd województw i ziem, w: Studia z dziejów Rzeczypospolitej szlacheckiej, red. K. Matwijowski, Z. Wójcik, Wrocław 1968, s. 151-159.
}

był tam jednostką często spotykaną, po czym nastąpiło stopniowe upodobnienie podziału województw ruskiego, bełskiego i podolskiego na powiaty do istniejących w innych częściach Korony ${ }^{23}$. W Wielkim Księstwie Litewskim powiat był terminem wieloznacznym do 1566 r., kiedy to wprowadzono podział województw na powiaty na takich samych zasadach jak w Koronie.

Przebieg granic powiatu warunkowały przede wszystkim stosunki własnościowe, ale nie był to stosunek ścisły, tylko sądowy. Granice państwa i województw, warunki geograficzne (lasy, rzeki, bagna) służyły temu tylko w ograniczonym stopniu, a stare podziały na kasztelanie - tylko w niektórych przypadkach. Na przebieg granic powiatów nie miały wpływu administracyjne podziały kościelne.

W XVI w. wytworzył się związek między powiatem a organizacją skarbowości Rzeczypospolitej. Jego charakter był wyłącznie porządkujący, gdyż administracja skarbowa tylko pomocniczo wykorzystywała schemat podziału na powiaty w organizacji ściągania podatków (ewidencji podatników). Jedynie w tym sensie można mówić o powiecie skarbowym. $\mathrm{Na}$ ogół granice powiatów sądowych i skarbowych pokrywały się. Na ogół - gdyż spisujący rejestry poborcy podatkowi i ich pisarze stosowali uproszczenia, czyniąc dla ułatwienia drobne odstępstwa od stanu rzeczywistego. Były jednak wyjątki, np. w Prusach Królewskich, gdzie dawny krzyżacki podział na liczne powiaty stopniowo zanikał, ustępując podziałowi sądowemu, przy czym organizacja sądownictwa ziemskiego wyglądała tam inaczej niż w innych częściach Korony ${ }^{24}$.

W województwie krakowskim bardzo obszerny krakowski powiat sądowy został przed 1564 r. podzielony przez poborców na dwa powiaty skarbowe, najpierw

\footnotetext{
${ }^{23}$ P. Dąbkowski, Podziat.

${ }^{24} \mathrm{M}$. Biskup, Podziały administracyjne województwa chełmińskiego w drugiej połowie XVI w., „Studia i Materiały do Dziejów Wielkopolski i Pomorza”, 1 (2, 2), 1956, s. 105-127.
} 
nazywane częściami powiatu krakowskiego, a potem - powiatami szczyrzyckim i proszowskim. Między 1612 a $1620 \mathrm{r}$. proszowski powiat skarbowy podzielono na krakowski i proszowski ${ }^{25}$.

Ponieważ powiat był najmniejszą jednostką podziału terytorialnego kraju, poborcy i ich pisarze wykorzystywali w celu łatwiejszej ewidencji podatników sieć parafii rzymskokatolickich (w województwie krakowskim także parafii obrządku wschodniego), tzn. spisywali wsie parafiami, stosując czasem ze względów utylitarnych odstępstwa od rzeczywistej przynależności parafialnej. Nie dotyczy to obszarów, na których rzymskokatolicka sieć parafialna była rzadka (województwo ruskie z wyjątkiem ziemi chełmskiej, a także bełskie, wołyńskie, podolskie, bracławskie i kijowskie).

W XV i na początku XVI w. sieć powiatów ulegała znacznym zmianom, po czym ustabilizowała się. Najpóźniejsze znane wypadki tworzenia w Koronie nowych powiatów to powstanie powiatu radziłowskiego w 1548 r. (wydzielonego z powiatów wiskiego i wąsoskiego województwa mazowieckiego) oraz serockiego między 1567 a 1591 r. (wydzielonego z powiatów nowomiejskiego i zakroczymskiego województwa mazowieckiego) ${ }^{26}$.

Źródłami do odtwarzania granic powiatów są rejestry poborowe (z pewnymi zastrzeżeniami), a ponadto mapy historyczne z XVIII w. i dokumenty.

Szczegółowy przebieg granic wojewódzkich i powiatowych odtworzony został w wydawnictwach z serii „Atlas historyczny Polski. Mapy szczegółowe XVI wieku”. Ukazały się tomy dotyczące województw krakowskiego, sandomierskiego,

\footnotetext{
${ }^{25}$ H. Rutkowski, Granice państwowych jednostek terytorialnych, w: Województwo krakowskie w drugiej połowie XVI wieku, cz. 2: Komentarze, indeksy, red. H. Rutkowski, Warszawa 2008 (Atlas historyczny Polski. Mapy szczegótowe XVI wieku, 1), s. 27-35.

${ }^{26}$ A. Dunin-Wąsowiczowa, Podziały administracyjne, w: Mazowsze w drugiej połowie XVI w., cz. 2: Komentarz, indeksy, red. W. Pałucki, oprac. A. Dunin-Wąsowiczowa i in., Warszawa 1973 (Atlas historyczny Polski. Mapy szczegółowe XVI wieku, 7), s. 35-63.
}

lubelskiego, sieradzkiego i łęczyckiego, mazowieckiego, płockiego i rawskiego oraz poznańskiego i kaliskiego ${ }^{27}$, a do 2020 r. mają być ukończone woluminy dotyczące Kujaw i województwa podlaskiego. Dla Prus Królewskich przydatne są opracowania Mariana Biskupa i Andrzeja Tomcza$\mathrm{ka}^{28}$, a dla Kujaw i ziemi dobrzyńskiej Zenona Guldona ${ }^{29}$.

Szczególnych kłopotów przysparza odtworzenie przebiegu granic jednostek terytorialnych Wielkiego Księstwa Litewskiego, zwłaszcza dla okresu po 1566 r. Ten, który widnieje na mapach $\mathrm{w}$ atlasach historycznych oraz mapach załącznikowych do rozmaitych monografii i opracowań, będzie wymagał weryfikacji na wielu odcinkach. Jedyne opracowanie zawierające odtworzenie granic tej części Rzeczypospolitej Obojga Narodów oparte na analizie materiałów szczegółowych to wydana w 1928 r. Mapa Wielkiego Księstwa Litewskiego w XVI w. Czesść pótnocna autorstwa Jana Jakubowskiego ${ }^{30}$, ukazująca stan sprzed $1566 \mathrm{r}$.

Osobnym zagadnieniem są okręgi podlegające w Rzeczypospolitej szlacheckiej

\footnotetext{
${ }^{27}$ Województwo krakowskie; Województwo sandomierskie w drugiej połowie XVI wieku, cz. 1-2, red. W. Pałucki, oprac. K. Chłapowski i in., Warszawa 1993 (Atlas historyczny Polski. Mapy szczegótowe XVI wieku, 2); Województwo lubelskie w drugiej połowie XVI wieku, red. W. Pałucki, oprac. S. Wojciechowski, Warszawa 1966 (Atlas historyczny Polski. Mapy szczegółowe XVI wieku, 3); Wielkopolska w drugiej połowie XVI wieku, cz. 1-2, red. K. Chłapowski, M. Słoń, oprac. A. Borek i in., Warszawa 2017 (Atlas historyczny Polski. Mapy szczegófowe XVI wieku, 4); Województwo sieradzkie i tęczyckie w drugiej połowie XVI wieku, cz. 1-2, red. H. Rutkowski, oprac. K. Chłapowski i in., Warszawa 1998 (Atlas historyczny Polski. Mapy szczegółowe XVI wieku, 5); Mazowsze, cz. 1-2. W każdym z tych tomów znajduje się rozdział poświęcony granicom administracji państwowej autorstwa odpowiednio: Henryka Rutkowskiego, Władysława Pałuckiego, Stefana Wojciechowskiego, Michała Gochny, ponownie Henryka Rutkowskiego i Anny Dunin-Wąsowiczowej.

${ }^{28}$ M. Biskup, A. Tomczak, Mapy województwa pomorskiego w drugiej połowie XVI w., „Roczniki Toruńskiego Towarzystwa Naukowego”, 58 (1), 1955; M. Biskup, Prusy Królewskie w drugiej połowie XVI wieku, współpr. L. Koc, Warszawa 1961 (Atlas historyczny Polski. Seria B: Mapy przeglądowe).

${ }^{29}$ Z. Guldon, Rozmieszczenie własności ziemskiej na Kujawach w II potowie XVI wieku, Toruń 1967; tenże, Mapy ziemi dobrzyńskiej w drugiej połowie XVI wieku, cz. 1: Podziały administracyjne, Toruń 1967.

${ }^{30} \mathrm{~J}$. Jakubowski, Mapa Wielkiego Księstwa Litewskiego w połowie XVI wieku, cz. 1: Część pótnocna, Kraków 1928.
} 
jurysdykcji starosty grodowego, w źródłach nazywane nieprecyzyjnie ziemiami. Jurysdykcja starosty grodowego w zakresie tzw. artykułów starościńskich mogła się rozciągać na kilka powiatów, np. w województwie krakowskim, sandomierskim czy sieradzkim. Jurysdykcja starosty generalnego Wielkopolski obejmowała powiat kościański i poznański województwa poznańskiego oraz pięć z sześciu powiatów województwa kaliskiego. W województwie podolskim jurysdykcja starosty grodowego obejmowała całe województwo (ziemię). W ziemi dobrzyńskiej i wschowskiej, województwach łęczyckim i płockim, a także mazowieckim, rawskim i ruskim, które dzieliły się na ziemie, jurysdykcja starosty grodowego obejmowała ziemię, a każda z nich podlegała osobnemu staroście grodowemu. W Prusach Królewskich jurysdykcja grodowa należała do wojewodów.

Liczba okręgów jurysdykcyjnych starostów grodowych w Koronie ustaliła się w końcu XV w. Względy praktyczne spowodowały, że w XVI stuleciu powstały trzy nowe starostwa grodowe (w $1554 \mathrm{r}$. wałeckie w województwie poznańskim, a w 1569 piotrkowskie w sieradzkim i stężyckie w sandomierskim), a siedziby starostów grodowych w Bielsku (województwo podlaskie) i Bracławiu (województwo bracławskie) zostały przeniesione odpowiednio do Brańska (przed 1565) i Winnicy (1598). Jurysdykcja sądowa starosty lubaczowskiego (województwo bełskie) ustała natomiast po 1534 r., a objęty nią obszar włączono do jurysdykcji starosty bełskiego ${ }^{31}$.

W Wielkim Księstwie Litewskim okręgi jurysdykcyjne starostw grodowych zostały powołane w 1566 r. i obejmowały powiaty. W powiatach stołecznych jurysdykcja należała do wojewodów. W ziemi żmudzkiej uprawnienia starosty grodowego miał starosta żmudzki, a w województwie

${ }^{31}$ K. Chłapowski, Starostowie niegrodowi w Koronie 1565-1795 (materiały źródłowe), Warszawa-Bellerive-sur-Alier 2017, s. 36-37, 384. smoleńskim - wojewoda. Powyższe uwagi nie dotyczą podziału administracyjnego Inflant, gdzie prezydentury (od $1598 \mathrm{r}$. województwa) dzieliły się na liczne małe okręgi (w sumie ok. pięćdziesięciu), w źródłach spisanych po łacinie określane jako districtus, a w polskojęzycznych - jako powiat, który jednak niewiele miał wspólnego z jednostkami o tej nazwie na innych ziemiach, np. w Koronie.

Były też dwie specjalne jednostki administracyjne. Pierwsza to przyłączona do Królestwa Polskiego w 1466 r. Warmia - terytorium będące uposażeniem biskupstwa warmińskiego, które zachowało status odrębnej jednostki administracyjnej z suwerenną władzą administracyjną i sądowniczą biskupa. Druga to księstwo siewierskie, zakupione w 1443 r. przez biskupa krakowskiego od księcia cieszyńskiego $^{32}$. Biskupi krakowscy sprawowali tam suwerenną władzę aż do 1790 r., kiedy księstwo to zostało wcielone do województwa krakowskiego.

Szczególną jednostką podziału terytorialnego był prywatny powiat szczebrzeski (szczebrzeszyński), będący częścią powiatu krasnostawskiego ziemi chełmskiej województwa ruskiego ${ }^{33}$. Miał on własne władze (wyznaczane przez dziedzica powiatu i jemu podległe), których jurysdykcji podlegała zamieszkująca na jego terenie szlachta. Nie był jednak osobnym powiatem skarbowym.

W drugiej połowie XVI w. podział administracyjny Rzeczypospolitej Obojga Narodów na województwa ostatecznie się ustabilizował i do 1793 r. nie ulegał zmianom poza wymuszonymi utratą terytoriów na rzecz Rosji i Szwecji oraz utworzeniem w 1768 r. województwa gnieźnieńskiego. Według stanu powstałego na skutek unii lubelskiej (1569) zawierał się

${ }^{32}$ Z. Noga, Sprzedaż terytorium siewierskiego biskupowi i kapitule krakowskiej w 1443 roku, „Rocznik Naukowo-Dydaktyczny. Prace Historyczne", 12, 1987, s. 93-104.

${ }^{33}$ M. Stankowa, Dawny powiat szczebrzeski. XIV-XVIII w., Warszawa 1975. 
w ramach ogólnego podziału Korony na dwie prowincje - Wielkopolskę i Małopolskę, którego geneza sięgała zamierzchłych czasów. Formalnie został on utrwalony przez Kazimierza Wielkiego, który wydał dwa oddzielne uregulowania prawne (statuty) dla Wielkopolski i Małopolski, a w 1578 r. ugruntowany przez utworzenie dla każdej z tych prowincji osobnego najwyższego sądu szlacheckiego, czyli Trybunału (w Piotrkowie i Lublinie). Po 1569 r. do prowincji małopolskiej zaczęto zaliczać województwa, które w następstwie unii lubelskiej przyłączyły się do Korony: wołyńskie, bracławskie i kijowskie. Wbrew powszechnie przyjętemu poglądowi po 1569 r. przynależność województwa podlaskiego do prowincji małopolskiej, a nie do wielkopolskiej, nie była oczywista, i to nawet dla samych zainteresowanych. Utrwaliła się stopniowo między 1578 a 1643 lub 1649 r. ${ }^{34}$

Według stanu powstałego na skutek unii lubelskiej podział administracyjny Rzeczypospolitej przedstawiał się następująco:

Prowincja wielkopolska: województwo poznańskie (3 powiaty i ziemia wschowska), kaliskie (6 powiatów), sieradzkie (4 powiaty i ziemia wieluńska, dzieląca się na 2 powiaty), łęczyckie ( 3 powiaty), brzeskie kujawskie (5 powiatów), inowrocławskie (2 powiaty), ziemia dobrzyńska (3 powiaty), rawskie (3 ziemie, każda po 2 powiaty), płockie (8 powiatów, przy czym mławski, niedzborski i szreński tworzyły ziemię zawkrzeńska), mazowieckie (10 ziem, z których wyszogrodzka i liwska nie dzieliły się na powiaty, a pozostałe na 2 , jak ziemia rożańska, do 4 powiatów).

Prusy Królewskie: województwo chełmińskie (2 powiaty: chełmiński i michałowski oraz 2 wydzielone jednostki administracyjne: terytoria biskupstwa chetmińskiego i miasta Torunia), malborskie

${ }^{34}$ E. Kalinowski, Podlasianin Wielkopolaninem? Z nieznanych dziejów przynależności terytorialnej Podlasia po 1569 roku, „Przegląd Historyczny", 106 (3), 2015, s. 421-439. (niepodzielone na powiaty), pomorskie (8 powiatów oraz miasto Gdańsk).

Prowincja małopolska: krakowskie (7, a z czasem 8 powiatów), sandomierskie (6 powiatów), lubelskie (3 powiaty), podlaskie (3 ziemie, zwane również powiatami), ruskie (5 ziem liczących 2-4 powiatów), bełskie ( 5 powiatów), wołyńskie (3 powiaty), podolskie (3 powiaty), kijowskie (3 powiaty), bracławskie (2 powiaty). Województwo czernihowskie w okresie znajdowania się w obrębie Rzeczypospolitej (formalnie 1635-1686, a faktycznie do 1667) dzieliło się na 2 powiaty.

Podzial administracyjny Wielkiego Księstwa Litewskiego po 1569 r. był następujący: województwo wileńskie (5 powiatów), trockie (4 powiaty), Żmudź ze starostą o uprawnieniach wojewody (29 włości, czyli ciwuństw), połockie (bez podziału na powiaty), witebskie (2 powiaty), nowogródzkie (3 powiaty), brzeskie-litewskie ( 2 powiaty), mińskie (3 powiaty), mścisławskie (bez podziału na powiaty), smoleńskie (okresowo w granicach Litwy 2 powiaty).

Śląsk od XIV w. należał do Królestwa Czech, a w 1526 r. stał się częścią monarchii Habsburgów, po 1648 r. zwanej Austrią. Składał się z Dolnego Śląska i Górnego Śląska, które dzieliły się na księstwa (a te z kolei na powiaty lub okręgi miejskie i państwa stanowe). Charakterystyczna była dwoistość administracji: państwowa (starostowie księstw i administracja lokalna) oraz stanowa - obie działające w ramach jednego podziału administracyjnego. $\mathrm{Na}$ Dolnym Śląsku było 11 księstw: głogowskie (6 powiatów), żagańskie (3 powiaty), jaworskie (4 okręgi miejskie), świdnickie (4 okręgi miejskie), legnickie (3 okręgi miejskie i 1 powiat), wołowskie (6 powiatów), oleśnickie (4 okręgi miejskie i 1 powiat), wrocławskie (4 okręgi miejskie), brzeskie (6 okręgów miejskich), ziębickie (2 okręgi miejskie), nyskie (ziemia nyska, powiat otmuchowski i 1 okręg miejski), hrabstwo kłodzkie (6 powiatów). Było tam 
też 8 państw stanowych. Górny Śląsk dzielił się na 5 księstw (opolskie, raciborskie, cieszyńskie, opawskie i karniowskie) oraz 9 państw stanowych (wśród których największe były Bytom i Pszczyna).

W 1742 r. Śląsk (z wyjątkiem części księstwa opawskiego, karniowskiego, nyskiego i niemal całego cieszyńskiego) stał się częścią państwa pruskiego. Otrzymał nazwę prowincji, którą podzielono na dwa departamenty kameralne - głogowski i wrocławski. Departament głogowski obejmował księstwa: głogowskie, jaworskie, legnickie, wołowskie, żagańskie i siedem wolnych państw stanowych, a wrocławski - księstwa brzeskie, część karniowskiego, część nyskiego, oleśnickie, część opawskiego, opolskie, raciborskie, świdnickie, wrocławskie i ziębickie oraz sześć wolnych państw stanowych. Departamenty kameralne podzielono na powiaty, przy czym dość ściśle trzymano się dawnych granic księstw, wolnych państw stanowych i okręgów miejskich. Zmiany polegały głównie na łączeniu mniejszych jednostek w większe. Ogółem w pruskiej części Śląska utworzono 48 powiatów. Obok powiatów wiejskich istniały departamenty miejskie, kantony wojskowe i rejencje sądowe ${ }^{35}$.

Państwo krzyżackie po 1466 r. dzieliło się na komturstwa, a te z kolei na wójtostwa, prokuratorie i komornictwa. Komturie pełnity funkcje administracyjne, sądowe i policyjne. W 1506 r. obowiązywał też podział na 5 okręgów wojskowych (Orte). Po 1526 r. Prusy Książęce zostały podzielone na 3 okręgi (Kreise) i 39 starostw (Amte), z których część dzieliła się na okręgi zwane Kameramter ${ }^{36}$.

W istniejącym do 1637 r. Księstwie Pomorskim (Zachodniopomorskim) podział

\footnotetext{
${ }^{35}$ Historia Śląska, t. 1: Do roku 1763, cz. 3: Od końca XVI w. do r. 1763 red. K. Maleczyński, Wrocław-Warszawa 1963, s. 404-421; tamże, t. 2: 1763-1850, cz. 1: 1763-1806, red. W. Długoborski, WrocławWarszawa 1966, s. 71-75.

${ }^{36} \mathrm{~J}$. Małtek, Granice państwowe, kościelne i administracyjne Prus Książęcych w XVI wieku, „Komunikaty Mazursko-Warmińskie”, 1, 1966, s. 131-139.
}

administracyjny obejmował tylko dobra książęce zorganizowane w okręgi (Amte) wokół zamków będących siedzibami domen książęcych. Brandenburska część Pomorza (tzw. Pomorze Tylne) dzieliła się na jednostki administracyjno-podatkowe (domeny) oraz dwa rodzaje szlacheckich okręgów samorządowo-podatkowych, w zależności od stopnia zamożności szlachty.

Część Brandenburgii niemal całkowicie oddzielająca Księstwo Pomorskie od Wielkopolski (na niewielkim odcinku graniczyło z województwem kaliskim) nazywano Nową Marchią. Była to osobna jednostka terytorialna dzieląca się na 4-5 landwójtostw, a te z kolei - na okręgi. W latach 1402-1454 Nowa Marchia należała do Krzyżaków, a w latach 1535-1571 była osobnym księstwem w ramach Cesarstwa Rzymskiego Narodu Niemieckiego ${ }^{37}$.

Kwestia wykreślenia na mapach historycznych granic stała się przedmiotem dyskusji historyków i ich problemem badawczym.

W 1880 r. Stanisław Smolka poddał pod dyskusję projekt opracowania szczegółowej mapy historycznej ziem polskich na podstawie analizy przekazów źródłowych z XV i XVI w., w tym przeprowadzenia dokładnej analizy przebiegu granic ${ }^{38}$. Zbiegło się to z publikacją serii pt. Polska XVI w. pod względem geograficzno-statystycznym ${ }^{39}$, na którą składały się głównie publikacje rejestrów podatkowych (poborowych) poszczególnych województw, a w odniesieniu do Ukrainy - także materiałów z ksiąg sądowych. Twórcy tej serii, Adolf Pawiński i Aleksander Jabłonowski, zakładali, że następnym etapem będzie opracowanie map.

\footnotetext{
${ }^{37}$ Historia Pomorza, t. 2: 1466-1813, cz. 1: 1466-1648/1657, red. G. Labuda, Poznań 1976, s. 42-45, 122-124, 432-435; tamże, cz. 3: Pomorze Zachodnie, red. Z. Szultka, H. Lesiński, Poznań 2003, s. $270-276$.

${ }^{38} 0$ dziejach koncepcji i realizacji idei "Atlasu historycznego Polski” zob. B. Konopska, Polskie atlasy historyczne: koncepcje i realizacje, Warszawa 1994.

${ }^{39}$ Polska XVI w. pod względem geograficzno-statystycznym, red. A. Pawiński i in., t. 1-13, Warszawa 1883-1915 (Źródła Dziejowe, 12-24).
} 
Ponieważ Pawiński zmarł przedwcześnie, zamiar ten realizował jedynie Jabłonowski. Przygotował on Atlas historyczny Rzeczypospolitej Polskiej, t. 1: Epoka przetomu XVI na XVII-sty, dział 2: "Ziemie Ruskie" Rzeczypospolitej ${ }^{40}$, obejmujący województwa: ruskie, bełskie, podolskie, wołyńskie, bracławskie i kijowskie. Granice wykreślił na mapie w skali 1:300 000, przy czym metody wyznaczania granic $i$ ich generalizacja kartograficzna zależały od ilości i jakości materiałów źródłowych (w tym rzadkich aktów granicznych) oraz chwiejności granic. Na terenach gęsto zaludnionych prowadził je metodą interpolacji, na słabo zaludnionych uwzględnił dorzecza i roztoki graniczne, wykorzystywał granice majątków ziemskich, a czasem wyznaczał granice matematycznie. Dalsze prace uniemożliwiła pierwsza wojna światowa ${ }^{41}$.

W 1921 r. powstała Komisja dla Atlasu Historycznego Polski, której zadaniem było opracowanie i wydanie atlasu o charakterze naukowym. Powstały wówczas dwie koncepcje. Jedna zakładała opracowanie map przekrojowych w skali 1:200 000 dla trzech lub czterech przekrojów chronologicznych, a druga opracowanie map przekrojowych i rozwojowych. Różnice dotyczyły też kolejności badań. Jedni badacze uważali, że ze względu na obfitość źródeł kartograficznych i statystyczno-opisowych należy najpierw opracować przekrój dla drugiej połowy XVIII w., a potem poszerzać badania metodą retrogresji na przekroje wcześniejsze, uboższe źródłowo. Inni proponowali rozpoczęcie badań od XVI stulecia. Ostatecznie uznano, że najpierw zostanie opracowana mapa Polski XVIII w., a potem mapa Polski XVI w.

\footnotetext{
${ }^{40}$ A. Jabłonowski, Atlas historyczny Rzeczypospolitej Polskiej wydany z zasiłkiem Akademii Umiejętności w Krakowie, [t. 1:] Epoka przetomu z wieku XVI-go na XVII-sty, dział 2: „Ziemie Ruskie” Rzeczypospolitej, Warszawa-Wiedeń 1899-1904.

${ }^{41}$ T. Manteuffel, Metoda oznaczania granic w geografii historycznej, w: Księga pamiątkowa ku uczczeniu dwudziestopięcioletniej dziatalności naukowej prof. Marcelego Handelsmana, Warszawa 1929, s. 221-233. W toku prac nad „Atlasem historycznym Polski” metoda została dopracowana i rozwinięta.
}

Przygotowanie tego typu materiałów wymagało ogromu prac, a zespoły badawcze były nieliczne. Do wybuchu drugiej wojny światowej wydano Mape województwa krakowskiego $w$ dobie Sejmu Czteroletniego (1788-1792) w skali 1:200 000, opracowaną przez zespół pod kierunkiem Władysława Semkowicza na podstawie źródeł podatkowych, lustracji dóbr królewskich, spisów ludności, spisów kościelnych i źródeł kartograficznych. Wykreślono na niej granice województwa, powiatów, gmin i jednostek administracji kościelnej (diecezji, archidiakonatów, dekanatów i parafii), uzyskując względną dokładność ich przebiegu ${ }^{42}$.

Opublikowana została również wspomniana już Mapa Wielkiego Księstwa Litewskiego w potowie XVI w. Czesść pótnocna w skali 1:1 600000 autorstwa Jana Jakubowskiego. Mapa przedstawia stan sprzed reformy administracyjnej w 1566 r.: granice województw, obszaru „włości ruskich”, posiadłości wielkopańskich, powiatów i większych włości. Podstawą jej przygotowania były popisy wojskowe, lustracje starostw, opisy dóbr biskupich i wiele innych źródeł. Uzupełnieniem jest mapa pt. Nowy podziat administracyjny W. Księstwa Litewskiego $1566 r$. i granica z Korona $1569 r$. w skali 1:8000 $000^{43}$.

Trzeba też wspomnieć o dwóch opracowaniach mniejszych obszarów, wykonanych na podstawie źródeł historycznych. W 1921 r. ukazała się przygotowana przez Piotra Hrabyka Mapa orientacyjna ziemi przemyskiej i lwowskiej w skali 1:600 000 ${ }^{44}$, a w 1935 - opracowana przez Jana Jakubowskiego mapa Powiat grodzieński XVI w. ${ }^{45}$ w skali 1:200 000, do dziś wysoko oceniana za podstawy źródłowe i metodę wykonania.

\footnotetext{
${ }^{42}$ Mapa województwa krakowskiego z doby Sejmu Czteroletniego (1788-1792), red. W. Semkowicz, Kraków 1930.

${ }^{43}$ Jest to aneks zamieszczony na arkuszu wspomnianej wyżej mapy.

${ }^{44}$ P. Hrabyk, Ziemia przemyska i Iwowska (szkic historyczny z mapa), Przemyśl 1921; tenże, Granice ziemi przemyskiej i lwowskiej (objaśnienie do mapy), „Rocznik Przemyski”, 3, 1913-1922, s. 358-367. ${ }^{45} \mathrm{~J}$. Jakubowski, Powiat grodzieński w XVI wieku, „Prace Komisji Atlasu Historycznego", 3, 1935, s. 99-114.
} 
Podczas drugiej wojny światowej podstawowe materiały geograficzno-statystyczne proweniencji świeckiej dotyczące XVIII w. uległy niemal całkowitemu zniszczeniu. W 1948 r. reaktywowano Komisję dla Atlasu Historycznego Polski i rozpoczęła się dyskusja nad metodyką prac, w wyniku której zdecydowano o przyjęciu nowej skali dla mapy głównej (1:500 000), ograniczeniu prac nad przekrojem XVIII w. do tych obszarów, dla których przed 1939 r. sporządzono kartoteki osadnicze zawierające wypisy z materiałów źródłowych, które przestały istnieć podczas wojny (województwa sieradzkie, sandomierskie i lubelskie), oraz o rozszerzeniu zakresu o Śląsk, skupieniu się na przekroju XVI w. i uzupełnieniu map ogólnych mapami i kartogramami problemowymi.

W 1953 r. w ramach nowo powstałego Instytutu Historii PAN utworzono Zakład Atlasu Historycznego po kierunkiem Stanisława Herbsta, a później Władysława Pałuckiego, Stanisława Trawkowskiego, Małgorzaty Wilskiej i Marka Słonia. W 1958 r. opublikowane zostało tam opracowanie pt. Województwo ptockie okoto 1578 roku, w skład którego wchodziły mapa główna w skali 1:200 000 oraz dziewięć kartogramów w skali 1:500 000. Na mapie głównej pokazane zostały m.in. państwowe i kościelne podziały administracyjne. Granice rekonstruowano metodą interpolacji, poczynając od odtworzenia najmniejszych jednostek terytorialnych, czyli parafii, a następnie przechodząc do wyznaczenia granic powiatów, ziem i województw ${ }^{46}$.

W tym samym czasie Marian Biskup opublikował wspomnianą już mapę przeglądową Prus Królewskich w XVI w. w skali 1:500 $000^{47}$.

W wyniku szerokiej dyskusji program prac atlasowych został zmieniony. Zrezygnowano $\mathrm{z}$ map problemowych, a mapy

\footnotetext{
${ }^{46}$ Województwo płockie około 1578 r., red. S. Herbst, oprac. I. Gieysztorowa i in., Warszawa 1958.

${ }^{47}$ M. Biskup, Prusy Królewskie.
}

szczegółowe ograniczono do ziem polskich Korony. Poczynione zostały też plany wydania ośmiu zeszytów/tomów składających się z mapy głównej w skali 1:250 000, map załącznikowych i tekstowych, komentarza oraz indeksów miejscowości i obiektów fizjograficznych. Miały one objąć: 1. województwo krakowskie, 2. województwo sandomierskie, 3. województwo lubelskie, 4. Wielkopolskę (województwa poznańskie i kaliskie), 5. województwa łęczyckie i sieradzkie z ziemią wieluńską, 6. Kujawy (województwa brzeskie kujawskie i inowrocławskie z ziemią dobrzyńska), 7. Mazowsze (województwa płockie, rawskie i mazowieckie), 8. Podlasie.

Do 2018 r. wydane zostały zeszyty/ tomy: $1,2,3,4,5$ i $7^{48}$, a 6 i 8 mają być ukończone w 2020 r. Przed kilku laty zdecydowano o przygotowaniu zeszytu/ tomu 9, dotyczącego Prus Królewskich. Z przyczyn pozamerytorycznych zrezygnowano natomiast z zapowiadanego tomu/ zeszytu 10 - o Warmii.

$\mathrm{Na}$ mapach głównych w każdym z tomów/zeszytów zostały wykreślone granice jednostek administracji państwowej i kościelnej, w każdym z komentarzy znajduje się rozdział, w którym omówiono podstawy źródłowe i metody wykreślenia granic, a także trudności, na które napotkali autorzy, i sposoby ich rozwiązywania.

Granice jednostek administracji państwowej wykreślił też Zenon Guldon na mapach załącznikowych do swoich opracowań własności ziemskiej na Kujawach i w ziemi dobrzyńskiej ${ }^{49}$. Prace nad mapami województw sieradzkiego,

\footnotetext{
${ }^{48}$ Zob. przyp. 26. W poszczególnych tomach znajdują się rozdziały poświęcone państwowym i kościelnym podziałom administracyjnym oraz trudnościom przy wykreślaniu granic. Z wcześniejszych prac poświęconych podziałom administracyjnym w województwach opracowanych w tej serii wymienić trzeba: Z. Kozłowska, Mapa historyczna granic politycznych i kościelnych powiatu proszowskiego, „Prace Komisji dla Atlasu Historycznego Polski", 1, 1922, s. 17-26; S. Arnold, Podziaty administracyjne województwa sandomierskiego do końca w. XVIII, w: Pamiętnik świętokrzyski, Kielce 1931, s. 59-62; S.M. Zajączkowski, 0 ksztattowaniu się granic dawnych ziem tęczyckiej i sieradzkiej do XVI w., „Slavia Antiqua”, 198, 1971, s. 123-172.

${ }^{49}$ Z. Guldon, Rozmieszczenie; tenże, Mapy.
} 
sandomierskiego i lubelskiego w XVIII w. zostały natomiast zaniechane.

Wielkie osiagnięcie stało się udziałem nieistniejącej już Wrocławskiej Pracowni Zakładu Atlasu Historycznego, kierowanej przez Tadeusza Ładogórskiego, a następnie Juliana Janczaka. Przygotowano tam dwutomowy Atlas historyczny Ślaska w końcu XVIII w., składający się z przeglądowej mapy osadniczej w skali 1:500 000, licznych map problemowych i obszernych komentarzy. Na mapie głównej przedstawiono granice prowincji śląskiej, departamentów kameralnych i powiatów ok. 1787 r., a w komentarzu - podstawy źródłowe i metody wykreślenia granic ${ }^{50}$.

Granice jednostek administracji Kościoła katolickiego w Koronie i Wielkim Księstwie Litewskim (później w Rzeczypospolitej Obojga Narodów) dzieliły się na granice prowincji, diecezji, archidiakonatów, dekanatów i parafii. W połowie XV w. na obszarze Królestwa Polskiego podział na prowincje i diecezje był już ukształtowany ${ }^{51}$. Istniały wówczas dwie prowincje - gnieźnieńska i lwowska.

Prowincja gnieźnieńska dzieliła się na diecezje: gnieźnieńską, krakowską, poznańska, wrocławska, płocką i włocławska, wileńską, żmudzką, kamieńską (do 1556), lubuską (do 1556), inflancką (od 1583) i smoleńską (od 1636).

Termin archidiecezja na oznaczenie stołecznej diecezji prowincji gnieźnieńskiej

\footnotetext{
${ }^{50}$ Atlas historyczny Polski. Mapy XVIII w. Śląsk w drugiej połowie XVIII wieku, t. 1, cz. 1-2, red. J. Janczak, T. Ładogórski, Wrocław 1976; tamże, t. 2, cz. 1-2, red. J. Janczak, Wrocław 1984.

${ }^{51}$ Ogólnie na temat diecezji i ich granic: W. Müller, Diecezje w okresie potrydenckim, w: Kościół w Polsce, t. 2, red. J. Kłoczowski, Kraków 1969, s. 57-258; B. Kumor, Granice metropolii i diecezji polskich 966-1939, Lublin 1972; S. Litak, Struktura terytorialna Kościoła tacińskiego w Polsce w 1772 r., Lublin 1980; tenże, Kościót taciński w Rzeczypospolitej. Struktury organizacyjne, Lublin 1996; tenże, Atlas Kościoła łacińskiego w Rzeczypospolitej Obojga Narodów w XVIII wieku, Lublin 2006; B. Szady, Geografia struktur religijnych i wyznaniowych w Koronie w II połowie XVIII wieku, Lublin 2010 (zwłaszcza: Źródła i opracowania - s. 7-16, 259-278; Opracowania - s. 259-278). Ponadto w każdym tomie serii „Atlas historyczny Polski. Mapy szczegółowe XVI wieku" znajdują się poświęcone podziałom kościelnym rozdziały pióra Anny Dunin-Wąsowiczowej, Henryka Rutkowskiego, Marty Piber-Zbieranowskiej, Arkadiusza Borka i Bogumiła Szadego.
}

pojawił się po raz pierwszy w 1572 r., ale aż do rozbiorów w statutach synodalnych i w innych aktach kościelnych spisywanych po łacinie częściej występował termin diecezja. W źródłach świeckich, spisywanych po polsku, termin archidiecezja występował bardzo rzadko. Diecezja gnieźnieńska graniczyła od zachodu z poznańską i wrocławską, od wschodu z włocławską, krakowską, poznańską (archidiakonat warszawski) i - na krótkim odcinku z płocką.

Diecezja krakowska graniczyła od południa z metropolią ostrzyhomską, od zachodu z diecezjami wrocławską i gnieźnieńską, od wschodu z prowincją lwowską (diecezjami chełmską i przemyską). Dwa dekanaty - bytomski i pszczyński - leżały poza granicami Korony (na Śląsku). Między 1604 a 1786 r. do diecezji krakowskiej należało starostwo spiskie ${ }^{52}$.

Diecezja poznańska na zachodzie graniczyła z diecezjami lubuską (do 1556) i wrocławską, na północy z kamieńską (do 1556), a na wschodzie z gnieźnieńską. Do diecezji poznańskiej należał archidiakonat warszawski, oddzielony od reszty diecezji terytorium diecezji gnieźnieńskiej, na północy graniczący z diecezją płocką, na zachodzie z włocławską, na południu z krakowską, a na wschodzie z łucką ${ }^{53}$.

Diecezja wrocławska graniczyła na południu z prowincją praska, na północy z diecezją lubuską (do 1556) i poznańską, a na wschodzie z poznańską i krakowską. Od połowy XVII w. związek diecezji wrocławskiej z prowincją gnieźnieńską był już tylko formalny (nominalny), ponieważ biskupi wrocławscy nie uznawali

\footnotetext{
${ }^{52}$ Oprócz pozycji wymienionych w poprzednim przypisie zob. rozdziały: Utworzenie biskupstwa w Krakowie i jego granice, w: B. Kumor, Dzieje diecezji krakowskiej do roku 1795, t. 1, Kraków 1998, s. 166-178 oraz Organizacja terytorialna diecezji krakowskiej, jej funkcje i działalność, w: tamże, t. 4, Kraków 2002, s. 21-171.

${ }^{53}$ Oprócz pozycji wymienionych w przypisie 51 zob. rozdziały: Granice historyczne archidiecezji poznańskiej, Archidiakonaty regionalne od 1298 i Rozwój organizacji dekanalnej w: J. Nowacki, Archidiecezja poznańska w granicach historycznych i jej ustrój, t. 2, Poznań 1964, s. 7-39, 287-298, 322-328.
} 
zwierzchnictwa arcybiskupów gnieźnieńskich, co demonstrowali na różne sposoby. Od 1748 r. egzempcja diecezji wrocławskiej nabrała znamion formalnych, ale arcybiskupi gnieźnieńscy nie rezygnowali ze swych pretensji. Ważne, że część diecezji wrocławskiej leżała $\mathrm{w}$ granicach Korony Polskiej (archiprezbiterat, czyli dekanat ostrzeszowski ze skrawkiem sycowskiego i jedna parafia $\mathrm{z}$ archidiakonatu opolskiego).

Diecezja płocka graniczyła od północy z chełmińską i warmińską, od zachodu z włocławską i gnieźnieńską, od wschodu z wileńską i metropolią lwowską (diecezją łucka), a od południa z diecezją poznańską (archidiakonatem warszawskim) $\mathrm{i}$ - na krótkim odcinku - z gnieźnieńską ${ }^{54}$.

Diecezja włocławska graniczyła na północy z Bałtykiem, na zachodzie z diecezją kamieńską (do 1534), na zachodzie i południu z gnieźnieńską, a na wschodzie z pomezańską (do 1525), chełmińską i płocką. W 1764 r. nastąpiła wymiana terytoriów z diecezją gnieźnieńską (dwanaście parafii w okolicy Bydgoszczy przeszło do diecezji gnieźnieńskiej w zamian za okręg Wolborz będący od tego czasu enklawą diecezji włocławskiej na terenie gnieźnieńskiej).

Diecezja wileńska graniczyła od północy z prowincją ryską (do 1566), na południu ze lwowską (diecezje łucka i kijowska), a na zachodzie z sambijską (do 1525), warmińską i płocką (na krótkim odcinku).

Diecezja żmudzka leżała nad Bałtykiem. Od zachodu i północy graniczyła z prowincją ryską (do 1566), od zachodu z diecezją sambijską prowincji ryskiej (do 1525), a na wschodzie z wileńską ${ }^{55}$.

Diecezja inflancka (początkowo wendeńska) erygowana została w 1583 r., a jej terytorium na mocy rozejmu w Mitawie (1622) i pokoju w Oliwie (1660) znacznie ograniczono.

\footnotetext{
${ }^{54}$ W. Müller, Organizacja terytorialna diecezji płockiej w XVI-XVIII wieku, „Roczniki Humanistyczne”, 15 (2), 1967, s. 129-174.

${ }^{55}$ G. Błaszczyk, Diecezja żmudzka od XV do początku XVII wieku. Ustrój, Poznań 1993.
}

W 1636 r. erygowano diecezję smoleńską (wyłączoną z obszaru kijowskiej). Objęła ona terytorium zdobyte ma Moskwie w 1611 r. i w 1634 liczyła tylko dziewięć parafii ${ }^{56}$.

$Z$ rozleglej prowincji ryskiej do pierwszej połowy XVI w. trzy diecezje leżały w całości lub części na terytorium Korony: chełmińska, pomezańska i warmińska.

Diecezja chełmińska w 1466 r. wróciła w granice Korony, zachowując przynależność do prowincji ryskiej. Gdy w $1566 \mathrm{r}$. ta ostatnia została zsekularyzowana, diecezja chełmińska weszła w skład prowincji gnieźnieńskiej (prawdopodobnie w 1589$)^{57}$.

Diecezja pomezańska w 1466 r. została przedzielona granicą polsko-krzyżacką, w wyniku czego po stronie polskiej zostało siedemdziesiąt parafii. W 1525 r. nastąpiła jej sekularyzacja, a polską część włączono do diecezji chełmińskiej.

Diecezja warmińska do 1466 r. leżała w państwie krzyżackim. W 1466 r. jej mniejsza część przypadła Polsce. W 1525 r. na skutek sekularyzacji przestała istnieć część krzyżacka. W 1549 r. diecezja została poddana bezpośrednio Stolicy Apostolskiej, z obowiązkiem udziału w synodach prowincji gnieźnieńskiej. Biskupi warmińscy nie poczuwali się jednak do podlegania tym decyzjom synodu, które im nie odpowiadaty $^{58}$.

Prowincja lwowska, utworzona w 1367 r. w Haliczu (od 1412 r. ze stolicą we Lwowie), składała się z diecezji: lwowskiej, przemyskiej, łuckiej, chełmskiej, kamienieckiej, kijowskiej i bakowskiej (od 1621).

Diecezja (archidiecezja) lwowska na wschodzie graniczyła z diecezjami kamieniecką i bakowską, na północy z chełmską i łucką, a na zachodzie z przemyską.

\footnotetext{
${ }^{56}$ T. Długosz, Dzieje diecezji smoleńskiej, Lwów 1937.

${ }^{57}$ A. Nadolny, Granice diecezji chełmińskiej, „Studia Pelplińskie”, 16, 1985, s. 15-25.

${ }^{58}$ A. Kopiczko, Ustrój i organizacja diecezji warmińskiej w latach 1525-1772, Olsztyn 1993.
} 
Południowa granica diecezji pokrywała się z granicą państwa ${ }^{59}$.

Diecezja przemyska graniczyła na wschodzie ze lwowską, na północy i zachodzie z krakowska, a na południu z prowincją ostrzyhomskąa .

Diecezja chełmska (od 1490 r. ze stolicą w Krasnymstawie) graniczyła od północy i wschodu z łucką, od zachodu z krakowską, a od południa z przemyską i lwowską.

Diecezja łucka graniczyła od północy z wileńską, od zachodu z płocką, poznańską (archidiakonat warszawski), krakowską i chełmską, od południa z lwowską i kamieniecką, a od wschodu z kijowską. Od końca XVI i przez XVII w. formalnie pozostawała w prowincji lwowskiej, ale biskupi łuccy uchylali się od uznawania zwierzchności arcybiskupów lwowskich i uważali się za podlegających arcybiskupom gnieźnieńskim. Formalnie zostało to zaakceptowane na początku XVIII w. ${ }^{61}$

Diecezja kamieniecka graniczyła od zachodu ze lwowską, od północy z łucką, od wschodu z kijowską, a od południa $\mathrm{z}$ bakowską ${ }^{62}$.

Diecezja kijowska od zachodu graniczyła z łucką, kamieniecką i bakowską, od północy z wileńską, a na wschodzie i południu jej granica pokrywała się z granicą państwa $^{63}$.

Diecezja bakowska do 1768 r. leżała w całości poza granicami Rzeczypospolitej.

Po pierwszym rozbiorze Rzeczypospolitej w 1772 r. rozpoczęły się starania o wyłączenie niegalicyjskich części diecezji chełmskiej, kamienieckiej oraz

${ }^{59} \mathrm{~J}$. Krętosz, Organizacja archidiecezji Iwowskiej obrządku łacińskiego od XV w. do 1772 roku, Lublin 1986.

${ }^{60}$ W. Müller, Organizacja terytorialna diecezji przemyskiej w okresie przedrozbiorowym (1375-1772), „Nasza Przeszłość”, 46, 1976, s. 29-52.

${ }^{61}$ L. Królik, Organizacja diecezji łuckiej i brzeskiej w XVII i XVIII wieku, Lublin 1983.

62 J. Mucha, Organizacja diecezji kamienieckiej do roku 1795, „Roczniki Teologiczno-Kanoniczne", 30 (4), 1983, s. 63-284.

${ }^{63}$ J. Chachaj, Stan i odbudowa sieci kościelnej w tacińskiej diecezji kijowskiej w drugiej połowie XVII i w XVIII wieku, „Archiwa, Biblioteki i Muzea Kościelne", 87, 2007, s. 5-62. kijowskiej z metropolii lwowskiej i związanie ich z gnieźnieńską. W sporządzonej w 1789 r. relacji arcybiskupa gnieźnienskiego Michała Jerzego Poniatowskiego o stanie metropolii znalazło się stwierdzenie, że należą do niej także diecezje chełmska, kamieniecka i kijowska, ale Stolica Apostolska nie zatwierdziła tego stanu. Istniała jednak jakaś ich nieusankcjonowana kanonicznie podległość wobec metropolii gnieźnieńskiej, gdyż świadczą o tym fakty.

Specyficzną i rzadką jednostką terytorialnej administracji kościelnej były sufraganie terenowe, które nie będąc diecezjami, pełnity ich rolę. W $1639 \mathrm{r}$. w diecezji wileńskiej powstała sufragania białoruska, a w drugiej połowie XVIII w. sufraganie trocka (diecezja wileńska), gdańska (diecezja włocławska), lubelska, sandomierska (diecezja krakowska), pułtuska (diecezja płocka) i łowicka (diecezja gnieźnieńska).

Podział diecezji na archidiakonaty powstawał stopniowo i nie we wszystkich diecezjach. Nie było ich w chełmińskiej, pomezańskiej, sambijskiej i warmińskiej, z wyjątkiem archidiakonatu utworzonego w 1745 r., a obejmującego obszar diecezji pomezańskiej, który po jej sekularyzacji włączony został do chełmińskiej. W diecezji wileńskiej jedynym archidiakonatem był utworzony w 1619 r. białoruski. W metropolii lwowskiej archidiakonaty utworzono dopiero w XVIII w. i tylko w diecezjach łuckiej, lwowskiej i przemyskiej; w żmudzkiej, inflanckiej i smoleńskiej nie było podziału na archidiakonaty.

W okresie, którego dotyczy ten tekst, podział diecezji na archidiakonaty ukształtowany w średniowieczu przedstawiał się następująco:

- diecezja gnieźnieńska: gnieźnieński, łęczycki, kaliski, kamieński (od 1512) ${ }^{64}$,

\footnotetext{
${ }^{64}$ A. Mietz, Archidiakonat kamieński archidiecezji gnieźnieńskiej. Struktura terytorialna i stan kościołów w czasach staropolskich 1512-1772, Włocławek 2005.
} 
wieluński, słupski, uniejowski, kurzelowski i łowicki (od 1522) ${ }^{65}$;

- diecezja krakowska: krakowski, lubelski, sandomierski, zawichojski, radomski, wiślicki, tarnowski, sądecki ${ }^{66}$ i wojnicki $(\text { od } 1751)^{67}$;

- diecezja poznańska: poznański, warszawski, pszczewski i śremski;

- diecezja wrocławska: wrocławski, głogowski, opolski i legnicki;

- diecezja płocka: płocki, dobrzyński i pułtuski (od 1443) ${ }^{68}$;

- diecezja włocławska: włocławski, pomorski i kruszwicki.

Dekanaty (w niektórych diecezjach zwane archiprezbiteratami) były mniejszymi okręgami administracji niż archidiakonaty ${ }^{69}$. W diecezji krakowskiej istniały jednostki wizytacyjno-administracyjne odpowiadające dekanatom, ale nazywane prepozyturami: wiślicka ${ }^{70}$, kielecka, tarnowska (od 1416) ${ }^{71}$ i pilicka (od 1612). W okresie staropolskim dekanaty obejmowały najczęściej po kilkanaście parafii, ale zdarzały się też liczące po dwadzieścia kilka, a wyjątkowo - ponad trzydzieści. Erygowanie nowych parafii powodowało z czasem konieczność dzielenia dekanatu na dwa, ale zdarzały się również przypadki odwrotne, gdy dwa małe dekanaty łączono w jeden. Biskupi dokonywali też reorganizacji sieci dekanalnych, czasem radykalnej, np. w diecezji gnieźnieńskiej w latach 1583-1596, w poznańskiej w roku 1602 i w płockiej w 1693. Z tych powodów

${ }^{65}$ J. Wieteska, Archidiakonat fowicki, Rzym 1966.

${ }^{66}$ B. Kumor, Archidiakonat sądecki. Opracowanie materiatów źródtowych do Atlasu Historycznego Kościoła w Polsce, „Archiwa, Biblioteki i Muzea Kościelne", 8, 1964, s. 271-303.

67 J. Szymański, Powstanie archidiakonatu wojnickiego i jego organizacja, „Roczniki Teologiczno-Kanoniczne", 5 (4), 1958, s. 83-102.

${ }^{68} \mathrm{~J}$. Wieteska, Materiały do atlasu historycznego Polski w XVIII w. Archidiakonat puttuski w ankiecie Michała Poniatowskiego z r. 1778, „Przegląd Historyczny”, 43 (2), 1952, s. 338-346.

${ }^{69}$ B. Kumor, Rozwój sieci dekanalnej w południowej części diecezji krakowskiej do 1772 r., „Roczniki Teologiczno-Kanoniczne”, 25 (1), 1978, s. 77-98.

${ }^{70}$ E. Wiśniowski, Prepozytura wiślicka do schyłku XVIII wieku. Materiały do struktury organizacyjnej, Lublin 1976.

${ }^{71}$ B. Kumor, Prepozytura tarnowska, „Archiwa, Biblioteki i Muzea Kościelne", 12, 1966, s. 207-288. liczba dekanatów w poszczególnych diecezjach była zmienna. W wileńskiej podział na dekanaty wprowadzony został krótko przed 1555 r., w żmudzkiej w 1587, a w tworzących metropolię lwowską jeszcze później: w łuckiej w 1589 r., we lwowskiej w 1593, w przemyskiej w 1594, w chełmskiej w 1604, w kamienieckiej w 1717 , a w kijowskiej w połowie XVIII w. W diecezji inflanckiej podziału na dekanaty nie było.

Wykazy dekanatów w poszczególnych diecezjach znamy z dokumentów i wykazów sporządzanych na polecenie biskupów, z ich relacji o stanie diecezji, wykazów podatku nadzwyczajnego płaconego przez duchownych, a począwszy od drugiej połowy XVI w. z protokołów wizytacji biskupich. Obowiązek dokonywania wizytacji wprowadził sobór trydencki. W diecezjach krakowskiej, włocławskiej, warmińskiej przemyskiej i żmudzkiej pierwsze wizytacje przeprowadzono przed 1600 r. Pierwsza zachowana wizytacja diecezji chełmińskiej pochodzi z lat 1640-1641, a przemyskiej z 1646 r. Diecezja gnieźnieńska po raz pierwszy wizytowana była w latach 16031607, poznańska w latach 1610-1619, wendeńska (inflancka) w 1613 r., wileńska i chełmska w XVII w., łucka w latach 1661-1664, a lwowska, kamieniecka i kijowska w pierwszej połowie XVIII w.

Protokoły wizytacji są bardzo ważnym źródłem dla badaczy zajmujących się geografią historyczną, ponieważ proboszczowie zobowiązani byli podawać nazwy osad należących do parafii (wizytacje diecezji poznańskiej z pierwszej połowy XVII w. takich informacji nie zawieraja, a najwcześniejsze wizytacje wielu diecezji nie objęły ich w całości). Możemy dzięki temu oznaczyć zasięg poszczególnych parafii. Trzeba jednak zauważyć, że dla administracji kościelnej nieistotne były tereny niezamieszkałe i nieuprawiane, ponieważ nie dotyczyła ich cura animarum ani dziesięcina czy inne opłaty kościelne. Linearne odkreślenie granic parafii nie było zatem 
dla proboszcza ważne, chyba że chodziło o miasta, w których było ich kilka.

Znajomość przynależności poszczególnych osad do parafii i wiedza o lokalnych stosunkach własnościowych pozwala nam ze znacznym stopniem prawdopodobieństwa nakreślić linearne granice parafii. Te zaś są podstawą dla wykreślenia granic dekanatów itd. Trudności pojawiają się w przypadku dużych obszarów leśnych lub górskich. W takich przypadkach granice parafii wykreślone na mapach mają charakter umowny, hipotetyczny, są bowiem wynikiem interpolacji lub wykorzystywania wizytacji i innych źródeł kościelnych powstałych w XVIII i XIX w. przy założeniu, że włączenie osad powstałych w XVII i XVIII w. do konkretnej parafii oznacza, że obszar, na którym te wsie założono, należy uznać za należący do niej wcześniej.

W okresie staropolskim podziały parafialne wykorzystywane były przez poborców podatkowych. Trzeba zwrócić uwagę, że ze względów utylitarnych nie przywiązywali oni wagi do ścisłego odwzorowywania w rejestrach przynależności parafialnej poszczególnych osad, jak również nie uwzględniali faktu powstania nowych parafii. Rejestrów poborowych nie należy więc traktować jako pewnej podstawy do określania przynależności parafialnej osad.

Liczba parafii ulegała zmianom. Stale powstawały kolejne, zwłaszcza na nowo zasiedlanych obszarach (np. leśnych czy podgórskich), na skutek inicjatywy mieszkańców lub dzięki działalności fundacyjnej właścicieli dóbr. Gęstość sieci parafialnej w poszczególnych diecezjach była bardzo różna.

W okresie rozpowszechniania się reformacji liczne kościoły parafialne zostały sprofanowane przez protestanckich kolatorów i pozbawione duszpasterzy, a część zamieniono na zbory. Powodowało to znaczne ubytki w sieci parafialnej, a np. w powiecie wałeckim niemal całkowity jej zanik. Czasem w miejscowościach dotychczas nieparafialnych powstawały nowe parafie, mające służyć obsłudze duszpasterskiej tej części ludności, która pozostała przy katolicyzmie. Ponadto w niektórych miejscowościach nieparafialnych powstawały budynki zborów, które po rekatolicyzacji stawały się kościołami parafialnymi. Niektóre sprofanowane lub zniszczone kościoły parafialne nigdy już nie odzyskały praw parafialnych lub nie zostały odbudowane. Po cofnięciu się fali reformacji następowała odbudowa sieci parafialnej, ale z różnych względów niekoniecznie w kształcie organizacyjnym z przeszłości.

Trzeba jeszcze wspomnieć o oficjalatach. Były to jednostki administracji kościelnej o charakterze sądowniczym. Ich granice nie pokrywały się w pełni z granicami archidiakonatów, gdyż było ich więcej niż tych ostatnich, a w mniejszych diecezjach oficjalaty nie istniały. Granice oficjalatów w okresie staropolskim to temat słabo rozpoznany, z wyjątkiem diecezji gnieźnieńskiej, krakowskiej i oficjalatu pomezańskiego $^{72}$.

W przypadku opactw, klasztorów i innych placówek duchowieństwa zakonnego możemy mówić o sieci, a nie o jednostkach terytorialnych mających granice linearne. Jeśli chodzi o granice jednostek administracyjnych Kościoła wschodniego w Koronie i Wielkim Księstwie Litewskim, a później w Rzeczypospolitej, to należy zacząć od informacji, że w 1458 r. powstała prawosławna metropolia w Kijowie, bezpośrednio zależna od patriarchatu konstantynopolitańskiego. Jej wschodnia granica pokrywała się ze wschodnią granicą Wielkiego Księstwa Litewskiego ${ }^{73}$. Metropolia

\footnotetext{
72 J. Rzepa, Organizacja terytorialna sądownictwa kościelnego w diecezji krakowskiej do pierwszego rozbioru Polski, „Roczniki Teologiczno-Kanoniczne", 4 (3), 1957, s. 83-102; P. Hemperek, Oficjalaty okręgowe w Polsce, „Roczniki Teologiczno-Kanoniczne”, 10 (5), 1971, s. 51-73; tenże, Oficjalat okręgowy w Lublinie XV-XVIII w. Studium z dziejów organizacji i kompetencji sądowej, Lublin 1974; A. Gąsiorowski, I. Skierska, Oficjalaty okręgowe w późnośredniowiecznej archidiecezji gnieźnieńskiej, „Czasopismo Prawno-Historyczne”, 47, 1995, s. 98-108; W. Zawadzki, Oficjalat pomezański w latach 1601-1821, „Zapiski Historyczne", 72, 2007, s. 23-52.

${ }^{73}$ L. Bieńkowski, Organizacja Kościoła wschodniego w Polsce, w: Kościół w Polsce, t. 2, s. 779-837; A. Mironowicz, Kościół prawosławny
} 
dzieliła się na dziesięć diecezji: kijowską, połocką, smoleńską, czernihowską (briańska), turowską (zwaną też pińska), łucką ${ }^{74}$, włodzimierską ${ }^{75}$, chełmską ${ }^{76}$, przemyską i halicką (od 1535 r. lwowska).

$\mathrm{Na}$ początku XVI w. diecezje czernihowska i smoleńska znalazły się poza granicami Wielkiego Księstwa Litewskiego. Rozmiary terytorialne poszczególnych diecezji były bardzo zróżnicowane.

Mniejszymi jednostkami podziałów administracyjnych Kościołów wschodnich były namiestnictwa, czyli protopopie. Aż do początku XVIII w. brakuje spisów i innych źródeł dotyczących protopopii, na podstawie których można by przeprowadzić badania pozwalające na odtworzenie przebiegu ich granic. Sieć parafii prawosławnych była bardzo gęsta. Ponieważ od ziemi będącej uposażeniem popa płacił on podatek, na podstawie rejestrów poborowych możemy odtworzyć sieć parafii prawosławnych, począwszy od początku XVI w.

W 1596 r. prawosławni biskupi diecezji kijowskiej, włodzimierskiej, łuckiej, połockiej, pińskiej ${ }^{77}$ i chełmskiej ${ }^{78}$ opowiedzieli się za unią z Kościołem rzymskokatolickim. Pozostali byli jej przeciwni ${ }^{79}$. W latach 1620-1621 nastąpiło odtworzenie hierarchii prawosławnej w Rzeczypospolitej (metropolii kijowskiej oraz diecezji przemyskiej, lwowskiej, połockiej, łuckiej

w dziejach dawnej Rzeczypospolitej, Białystok 2001; A. Gil, I. Skoczylas, Kościoły wschodnie w polsko-litewskim procesie przemian i adaptacji. Metropolia kijowska w latach 1458-1795, Lublin-Lwów 2014, w tym mapy na s. 449-460.

${ }^{74}$ A. Mironowicz, Biskupstwo turowsko-pińskie w XI-XVI wieku, Biatystok 2011

${ }^{75}$ Tenże, Diecezja włodzimierska do końca XVI wieku, Białystok 2013.

${ }^{76}$ A. Gil, Prawostawna diecezja chełmska do 1596 roku, Lublin-Chełm 1999

${ }^{77}$ W. Walczak, Unicka eparchia turowsko-pińska w XVII-XVIII wieku. Struktura organizacyjna, Białystok 2012; tenże, Spór o granice. Przynależność Mozyrowszczyzny do unickiej eparchii turowsko-pińskiej, w: Od Kijowa do Rzymu. Z dziejów stosunków Rzeczypospolitej ze Stolicą Apostolską i Ukrainą, red. M.R. Drozdowski, W. Walczak, K. Wiszowata-Walczak, Białystok 2012, s. 795-806.

${ }^{78}$ A. Gil, Chełmska diecezja unicka 1596-1810. Dzieje i organizacja, Lublin 2005.

${ }^{79}$ L. Bieńkowski, Kościót wschodni podzielony, w: Kościót w Polsce, t. 2, s. 838-1049. oraz na krótko włodzimierskiej i pińskiej), co sejm zaakceptował w latach 1632-1635. W ten sposób wytworzyły się dwie wzajemnie zwalczające się hierarchie Kościołów wschodnich. Istnienie unickiej diecezji przemyskiej było nieustabilizowane aż do 1670 r., a to z uwagi na niekonsekwentne deklaracje i postępowanie biskupów przemyskich obrządku wschodniego ${ }^{80}$.

Wybuch rebelii Chmielnickiego (1648), wojny z Rosją (1654) i okupowanie przez nią większości Wielkiego Księstwa Litewskiego (1654-1661) spowodowało czasowe załamanie się administracji Kościoła unickiego na znacznych obszarach oraz ekspansję prawosławia. Zawarcie w $1667 \mathrm{r}$. rozejmu w Andruszowie (potwierdzonego w 1686 r. pokojem Grzymułtowskiego, na mocy którego Rosja zrezygnowała ze znacznych obszarów Wielkiego Księstwa Litewskiego okupowanych po 1654 r., ale zatrzymała Zadnieprze wraz z Kijowem) spowodowało przeniesienie archikatedry unickiej z Kijowa do Lwowa, a przede wszystkim osłabienie prawosławia i odbudowę administracji unickiej. Od tego czasu proces ten stale postępowat. W 1692 r. przestała istnieć prawosławna diecezja przemyska, w 1700 - lwowska, a w 1715 - lucka. W 1772 r. na obszarze Rzeczypospolitej istniało 9300 cerkwi unickich i 497 prawosławnych. Należały one do powstałej w 1632 r. diecezji mohylewskiej (267 cerkwi), do której w $1661 \mathrm{r}$. włączono obszar likwidowanej diecezji połockiej, oraz do diecezji kijowsko-wileńskiej (230 cerkwi).

W Kościołach prawosławnym i unickim istniały protopopie (odpowiedniki dekanatów), przy czym w zależności od okresu w rozmaitym stopniu dostosowywano przebieg ich granic do granic wielkiej własności ziemskiej. Odtworzenie granic jednostek administracyjnych obu Kościołów wschodnich w tym okresie

\footnotetext{
${ }^{80}$ M. Bendza, Prawosławna diecezja przemyska w latach 1596-1670. Studium historyczno-kanoniczne, Warszawa 1982.
} 
możliwe jest dzięki materiałom źródłowym z XVIII w. ${ }^{81}$

W kościołach protestanckich zbór oznaczał wspólnotę wiernych, a nie jednostkę terytorialną, toteż możliwe jest jedynie przedstawienie sieci zborów, bez wyznaczania granic linearnych.

Jeśli chodzi o niechrześcijańskie wspólnoty wyznaniowe Rzeczypospolitej szlacheckiej (żydowskie, muzułmańskie czy karaimskie), to nie było tam organizacji terytorialnej w sensie jednostek mających granice linearne, a więc podobnie jak w przypadku zborów możliwe jest tylko przedstawienie sieci takich wspólnot.

Oprócz administracyjnych granic jednostek świeckich i kościelnych funkcjonowały granice własnościowe, czyli granice dóbr ziemskich. Oznaczano je kopcami wznoszonymi w pewnych odstępach, naciosami na drzewach (metoda zaniechana w XVIII w.), umieszczaniem kamieni z nacięciami, na mniejszych odcinkach za pomocą płotów lub rowów granicznych, a na jeziorach palami wbijanymi w dno. Wykorzystywano też drogi graniczne i miedze ${ }^{82}$.

Konieczność ustalania przebiegu granic własnościowych, spowodowana zawłaszczaniem gruntów niezagospodarowanych przez osadnictwo i powstawaniem sporów, pojawiła się już w średniowieczu. W konsekwencji była przedmiotem działań podejmowanych przez pracujące $\mathrm{w}$ terenie komisje graniczne złożone $\mathrm{z}$ przedstawicieli zainteresowanych stron, urzędników i świadków. Od XIV w. granice własnościowe stawały się linearne, a wpływ na to miały: rozwój osadnictwa, rozdrobnienie własności ziemskiej, rozpowszechnienie prawa niemieckiego, lokacje miast.

Od XV w. spory graniczne rozstrzygane były przez sądy podkomorskie (w wypadku dóbr prywatnych) lub komisje powoływane

\footnotetext{
${ }^{81}$ W. Kołbuk, Kościoły wschodnie w Rzeczypospolitej około 1772 roku. Struktury organizacyjne, Lublin 1998.

${ }^{82}$ S. Bylina, Drogi - granice - most. Studia o przestrzeni publicznej i sakralnej w średniowieczu, Warszawa 2012; G. Myśliwski, Powstanie i rozwój granicy liniowej na Mazowszu (XII - pot. XVI w.), „Kwartalnik Historyczny", 101 (3), 1993, s. 3-24.
}

przez króla i sejm, które działały w obecności podkomorzego (w wypadku dóbr królewskich). Z okresu od połowy XVI do XVIII w. zachowało się ponad trzydzieści ksiąg sądów podkomorskich województw poznańskiego, kaliskiego, sieradzkiego, tęczyckiego, inowrocławskiego, krakowskiego i lubelskiego (z lukami) zawierających protokoły rozgraniczeń, wizji i odnowień granicy $^{83}$. Są to szczegółowe opisy granic z powoływaniem się na znaki graniczne, zeznania świadków i dokumenty, przy czym dukty graniczne podkomorzowie lub komornicy (mianowani przez podkomorzego jego zastępcy) oglądali pieszo ${ }^{84}$.

Od drugiej połowy XVII w. podkomorzowie sporządzali mapy o bardzo rozmaitym poziomie wykonania, ale zachowały się tylko bardzo nieliczne z nich, ponieważ nie były dołączane do ksiąg podkomorskich, ale wręczane stronom. W drugiej połowie XVIII w. nastąpiło udoskonalenie techniki wykonania map podkomorskich (robiono to $\mathrm{z}$ udziałem geometrów), jak również ujednolicenie, zagęszczenie i wzmocnienie trwałości znaków granicznych ${ }^{85}$.

W księgach Metryki Koronnej można znaleźć wpisy protokołów czynności komisji, których zadaniem było rozstrzyganie sporów dotyczących przebiegu granic dóbr królewskich z prywatnymi ${ }^{86}$.

\footnotetext{
${ }^{83}$ W. Całczyński, Mapy sądów podkomorskich, komisarskich i trybunałów przechowywane w Archiwum Głównym Akt Dawnych w Warszawie, „Archeion”, 60, 1974, s. 159-174. Specjalnego rodzaju mapą graniczną jest mapa starostwa kamieńczykowskiego sporządzona na polecenie królowej Ludwiki Marii przed przekazaniem go warszawskim wizytkom. Zob. K. Chłapowski, Mapa graniczna starostwa kamieńczykowskiego z XVII wieku - nieznane źródło kartograficzne, „Kwartalnik Historii Kultury Materialnej", 26 (4), 1979, s. 497-503.

${ }^{84} \mathrm{~J}$. Gołaski, Technika rozgraniczenia dóbr ziemskich w końcu XVI i XVII w. w świetle poznańskich ksiąg podkomorskich (Z badań nad staropolską praktyką mierniczą), „Przegląd Geodezyjny”, 15, 1959, s. 439-455; 34, 1962, s. 267-271; tenże, Technika rozgraniczenia dóbr ziemskich w XVIII w. w świetle poznańskich ksiąg podkomorskich. Z badań nad staropolską praktyką mierniczą, „Przegląd Geodezyjny”, 33, 1961, s. 186-189, 228-232; J. Stoksik, ,Zjazdowy sąd komorniczy”: praktyka wytyczania granic przez Sąd Podkomorski, „Krakowski Rocznik Archiwalny", 17, 2011, s. 25-46.

${ }^{85}$ Taż, Geometrzy małopolscy do końca XVIII wieku: Z dziejów geodezji i kartografii wielkoskalowej w Polsce, Kraków 2013.

${ }^{86}$ Oryginalną, choć kontrowersyjną, koncepcję państw magnackich i ich granic przestawił Mariusz Kowalski: M. Kowalski, Księstwa Rzeczpospolitej. Państwo magnackie jako region polityczny, Warszawa 2013.
} 
Aneks

Podział administracyjny Rzeczypospolitej Obojga Narodów po 1569 roku7

\section{KORONA}

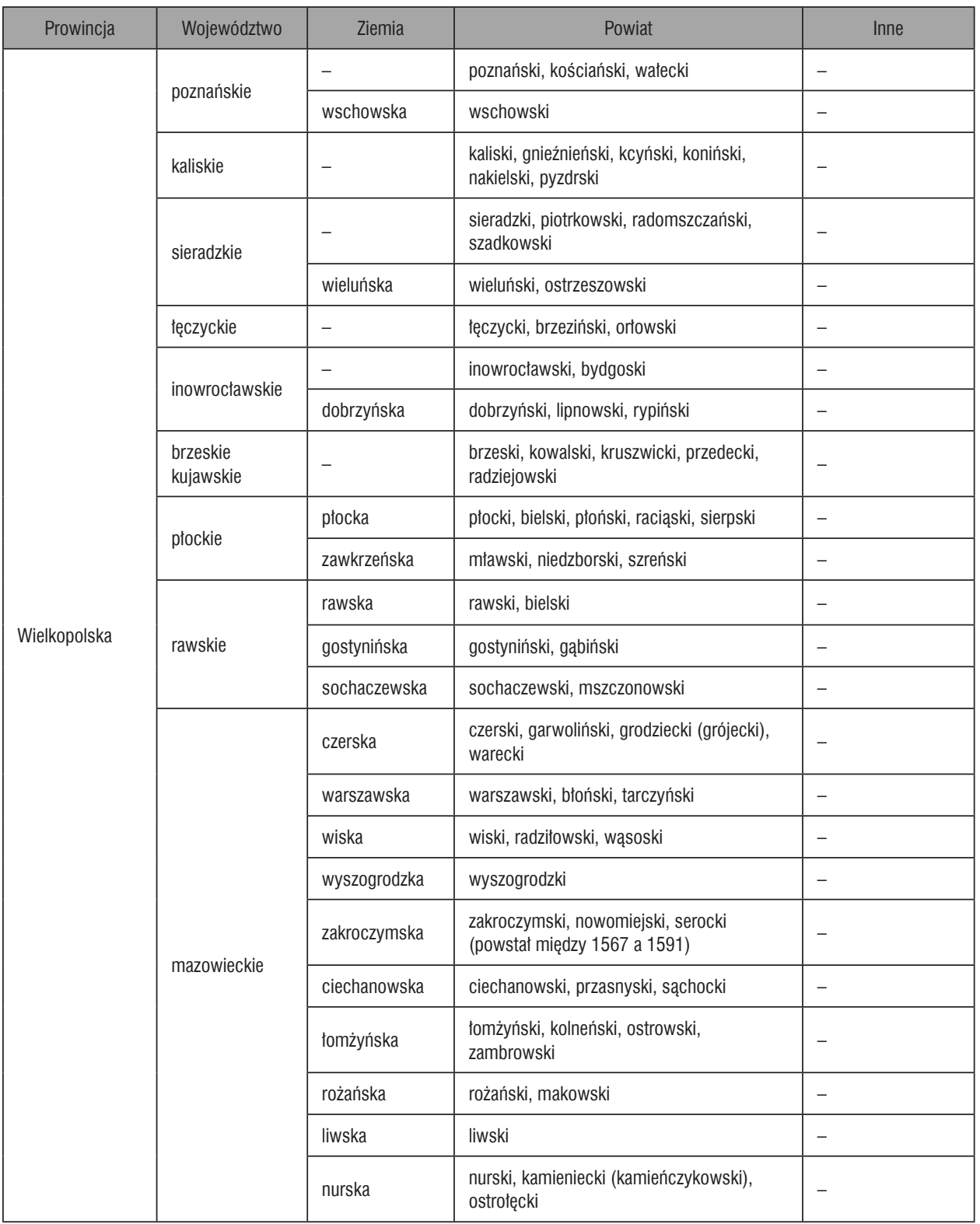

\footnotetext{
${ }^{87}$ Poniższe zestawienie jest nieco poprawione w stosunku do ustaleń Zygmunta Glogera. Por. Z. Gloger, Geografia historyczna dawnej Polski, Kraków 1900.
} 
Granice i podziały administracyjne Królestwa Polskiego i Rzeczypospolitej Obojga Narodów... Zapiski...

\begin{tabular}{|c|c|c|c|c|}
\hline Prowincja & Województwo & Ziemia & Powiat & Inne \\
\hline \multirow{6}{*}{$\begin{array}{l}\text { Wielkopolska } \\
\text { (Prusy } \\
\text { Królewskie) }\end{array}$} & \multirow{3}{*}{ chełmińskie } & \multirow{3}{*}{-} & chełmiński, michałowski & - \\
\hline & & & - & $\begin{array}{l}\text { terytorium biskup- } \\
\text { stwa chełmińskiego }\end{array}$ \\
\hline & & & - & $\begin{array}{l}\text { terytorium miasta } \\
\text { Torunia }\end{array}$ \\
\hline & \multirow{2}{*}{ pomorskie } & \multirow{2}{*}{-} & $\begin{array}{l}\text { człuchowski, gdański, mirachowski, nowski, } \\
\text { pucki, świecki, tczewski, tucholski }\end{array}$ & - \\
\hline & & & - & $\begin{array}{l}\text { terytorium miasta } \\
\text { Gdańska }\end{array}$ \\
\hline & malborskie & - & - & - \\
\hline \multirow{17}{*}{ Małopolska } & krakowskie & - & $\begin{array}{l}\text { biecki, księski, lelowski, proszowski } \\
\text { (od 1612/1620 krakowski i proszowski), } \\
\text { sądecki, szczyrzycki, śląski }\end{array}$ & - \\
\hline & sandomierskie & - & $\begin{array}{l}\text { sandomierski, chęciński, opoczyński, } \\
\text { pilzneński, stężycki, wiślicki }\end{array}$ & - \\
\hline & lubelskie & - & lubelski, łukowski, urzędowski & - \\
\hline & \multirow{3}{*}{ podlaskie } & bielska & bielski & - \\
\hline & & drohicka & drohicki & - \\
\hline & & mielnicka & mielnicki & - \\
\hline & \multirow{5}{*}{ ruskie } & Iwowska & Iwowski, żydaczowski & - \\
\hline & & chełmska & chełmski, krasnostawski & - \\
\hline & & halicka & halicki, kołomyjski, trembowelski & - \\
\hline & & przemyska & przemyski, drohobycki, samborski, stryjski & - \\
\hline & & sanocka & sanocki & - \\
\hline & bełskie & - & $\begin{array}{l}\text { bełski, buski, grabowiecki, horodelski, } \\
\text { lubaczowski }\end{array}$ & - \\
\hline & podolskie & - & kamieniecki, czerwonogrodzki, latyczowski & - \\
\hline & wołyńskie & - & krzemieniecki, łucki, włodzimierski & - \\
\hline & bracławskie & - & bracławski, winnicki & - \\
\hline & kijowskie & - & kijowski, owrucki, żytomierski & - \\
\hline & czernihowskie & - & czernihowski, nowogrodzki & - \\
\hline
\end{tabular}


WIELKIE KSIĘSTWO LITEWSKIE

\begin{tabular}{|l|l|l|}
\hline \multicolumn{1}{|c|}{ Województwo } & \multicolumn{1}{|c|}{ Powiat } & \multicolumn{1}{|c|}{ Inne } \\
\hline Wileńskie & $\begin{array}{l}\text { wileński, brasławski, lidzki, oszmiański, witkomierski } \\
\text { (w 1793 r. w województwie wileńskim utworzone zostały powiaty: } \\
\text { zawilejski, ejszyski i oniksztyński) }\end{array}$ & - \\
\hline Trockie & $\begin{array}{l}\text { trocki, grodzieński, kowieński, upicki (w 1791 r. w województwie trockim } \\
\text { utworzony został powiat preński, a w 1794- sokólski) }\end{array}$ & - \\
\hline- & - & Księstwo Żmudzkie \\
\hline Połockie & - & - \\
\hline Witebskie & witebski, orszański & - \\
\hline Nowogródzkie & nowogródzki, słonimski, wołkowyski & - \\
\hline Brzeskie-litewskie & brzeski, piński & - \\
\hline Mińskie & miński, mozyrski, rzeczycki & - \\
\hline Mścisławskie & - & smoleński, starodubowski (od 1625) \\
\hline Smoleńskie & & - \\
\hline
\end{tabular}

\section{KSIĘSTWO SIEWIERSKIE}

\section{WARMIA}

\section{INFLANTY}

Prezydentury (od 1598 r. województwa: dorpackie, parnawskie, wendeńskie, a od 1677 - województwo inflanckie)

\section{Bibliografia}

Alexandrowicz S., Kartografia Wielkiego Księstwa Litewskiego od XV do końca XVIII wieku, Warszawa 2012.

Arnold S., Podziaty administracyjne województwa sandomierskiego do końca w. XVIII, w: Pamiętnik świętokrzyski, Kielce 1931.

Atlas Historyczny Polski. Mapy XVIII w.: Ślask w drugiej potowie XVIII wieku, t. 1, cz.1-2, red. J. Janczak, T. Ładogórski, Wrocław 1976, t. 2, cz. 1-2, red. J. Janczak, Wrocław 1984.

Bardach J., Powiat w Polsce późnośredniowiecznej, „Czasopismo Prawno-Historyczne”, 19 (2), 1967.

Bendza M., Prawostawna diecezja przemyska $w$ latach 1596-1670. Studium historyczno-kanoniczne, Warszawa 1982.

Bieńkowski L., Kościót wschodni podzielony, w: Kościót w Polsce, t. 2, red. J. Kłoczowski, Kraków 1969.

Bieńkowski L., Organizacja Kościota wschodniego w Polsce, w: Kościót w Polsce, t. 2, red. J. Kłoczowski, Kraków 1969.
Biskup M., Podziaty administracyjne województwa chetmińskiego w drugiej potowie XVI w., „Studia i Materiały do Dziejów Wielkopolski i Pomorza”, $1(2,2), 1956$.

Biskup M., Prusy Królewskie w drugiej potowie XVI wieku, współpr. L. Koc, Warszawa 1961 (Atlas historyczny Polski. Seria B: Mapy przeglądowe).

Biskup M., Tomczak A., Mapy województwa pomorskiego w drugiej potowie XVI w., „Roczniki Toruńskiego Towarzystwa Naukowego", 58 (1), 1955.

Błaszczyk G., Diecezja żmudzka od XV do początku XVII w. Ustrój, Poznań 1993.

Błaszczyk G., Geografia historyczna Wielkiego Księstwa Litewskiego. Stan i perspektywy badań, wyd. 2, Poznań 2012.

Błaszczyk G., Powiat rosieński w XVII-XVIII wieku. Ze studiów nad podziatami administracyjno-terytorialnymi Żmudzi, „Zapiski Historyczne”, 51 (1), 1986. 
Błaszczyk G., Powiat szawelski w XVII-XVIII wieku. Ze studiów nad podziatami administracyjno-terytorialnymi Żmudzi, „Acta Baltico-Slavica”, 19, 1990.

Błaszczyk G., Powiat telszewski w XVII-XVIII wieku. Ze studiów nad podziatami administracyjno-terytorialnymi Żmudzi, „Acta Baltico-Slavica”, 19, 1990.

Błaszczyk G., Ze studiów nad podziatami administracyjno-terytorialnymi Żmudzi. Powiat wieloński w XVIIXVIII wieku, „Roczniki Historyczne”, 51, 1985.

Borek A., Granice jednostek administracji kościelnej. A. Diecezje gnieźnieńska i wtoctawska, w: Wielkopolska w drugiej potowie XVI wieku, red. K. Chłapowski, M. Słoń, Warszawa 2017 (Atlas historyczny Polski. Mapy szczegółowe XVI wieku, 4).

Buczek K., Dzieje kartografii polskiej od XV do XVIII wieku. Zarys analityczno-syntetyczny, Wrocław-Warszawa-Kraków 1963.

Budzyński Z., Kresy potudniowo-wschodnie w drugiej potowie XVIII wieku, t. 2: Atlas geograficzno-historyczny, Przemyśl-Rzeszów 2006.

Bylina S., Drogi - granice - most. Studia o przestrzeni publicznej $i$ sakralnej $w$ średniowieczu, Warszawa 2012.

Całczyński W., Mapy sądów podkomorskich, komisarskich i trybunatów przechowywane w Archiwum Gtównym Akt Dawnych w Warszawie, „Archeion”, 60, 1974.

Chachaj J., Stan i odbudowa sieci kościelnej w tacinskiej diecezji kijowskiej $w$ drugiej potowie XVII i w XVIII wieku, „Archiwa, Biblioteki i Muzea Kościelne”, 87, 2007.

Chłapowski K., Mapa graniczna starostwa kamieńczykowskiego z XVII wieku - nieznane źródto kartograficzne, „Kwartalnik Historii Kultury Materialnej”, 26 (4), 1979.

Chłapowski K., Starostowie niegrodowi w Koronie 1565-1795 (materiaty źródtowe), Warszawa-Bellerive-sur-Alier 2017.

Chodyła Z., Utworzenie i początki województwa gnieźnieńskiego (1768-1774-1776), w: Gniezno. Studia $i$ materiaty historyczne, t. 2, red. J. Topolski i in., Warszawa-Poznań 1987.

Dąbkowski P., Podziat administracyjny województwa ruskiego i betskiego w XV wieku, Lwów 1939.

Długosz T., Dzieje diecezji smoleńskiej, Lwów 1937.

Dunin-Wąsowiczowa A., Granice administracji kościelnej, w: Województwo sandomierskie $w$ drugiej potowie XVI wieku, red. W. Pałucki, Warszawa 1993 (Atlas historyczny Polski. Mapy szczegółowe XVI wieku, 2).

Dunin-Wąsowiczowa A., Podziaty administracyjne, w: Mazowsze w drugiej potowie XVI w., cz. 2: Komentarz, indeksy, red. W. Pałucki, Warszawa 1973 (Atlas historyczny Polski. Mapy szczegółowe XVI wieku, 7)
Gąsiorowski A., Powiatw Wielkopolsce XIV-XVI wieku. $Z$ zagadnień zarządu terytorialnego i podziatów Polski późnośredniowiecznej, Poznań 1965.

Gąsiorowski A., Skierska I., Oficjalaty okręgowe w późnośredniowiecznej archidiecezji gnieźnieńskiej, „Czasopismo Prawno-Historyczne”, 47, 1995.

Gierowski J.A., Szlachecki samorząd województw i ziem w XVI i XVII w., w: Studia z dziejów Rzeczypospolitej szlacheckiej, red. K. Matwijowski, Z. Wójcik, Wrocław 1968.

Gil A., Chetmska diecezja unicka 1596-1810. Dzieje i organizacja, Lublin 2005.

Gil A., Prawostawna diecezja chetmska do 1596 roku, Lublin-Chełm 1999.

Gil A., Skoczylas I., Kościoty wschodnie w polsko-litewskim procesie przemian i adaptacji. Metropolia kijowska w latach 1458-1795, Lublin-Lwów 2014.

Gloger Z., Geografia historyczna dawnej Polski, Kraków 1900.

Gniezno. Studia i materiaty historyczne, t. 2, red. J. Topolski i in., Warszawa-Poznań 1987.

Gochna M., Granice jednostek terytorialnych, w: Wielkopolska w drugiej potowie XVI wieku, red. K. Chłapowski, M. Słoń, Warszawa 2017 (Atlas historyczny Polski. Mapy szczegółowe XVI wieku, 4).

Godziszewski W., Granica polsko-moskiewska wedle pokoju polanowskiego (wytyczona w latach 1634-1648), „Prace Komisji Atlasu Historycznego Polski”, 3, 1935.

Gołaski J., Technika rozgraniczenia dóbr ziemskich w XVIII w. w świetle poznańskich ksiag podkomorskich ( $Z$ badan nad staropolska praktyka miernicza), „Przegląd Geodezyjny”, 33, 1961.

Gołaski J., Technika rozgraniczenia dóbr ziemskich w końcu XVI i XVII w świetle poznańskich ksiag podkomorskich ( $Z$ badan nad staropolska praktyka. miernicza), „Przegląd Geodezyjny”, 15, 1959; 34, 1962.

Guldon Z., Mapy ziemi dobrzyńskiej w drugiej potowie XVI wieku, cz. 1: Podziaty administracyjne, Toruń 1967.

Guldon Z., Rozmieszczenie wtasności ziemskiej na Kujawach w II potowie XVI wieku, Torun 1964.

Halecki O., Geografia polityczna ziem ruskich Polski i Litwy 1340-1569, „Sprawozdania Towarzystwa Naukowego Warszawskiego", 10, 1917.

Hemperek P., Oficjalat okręgowy w Lublinie XVXVIII w. Studium z dziejów organizacji i kompetencji sądowej, Lublin 1974.

Hemperek P., Oficjalaty okregowe w Polsce, „Roczniki Teologiczno-Kanoniczne”, 10 (5), 1971.

Historia Pomorza, t. 2: 1466-1813, cz. 1: 14661648/1657, red. G. Labuda, Poznań 1976.

Historia Pomorza, t. 2: 1466-1813, cz. 3: Pomorze Zachodnie, red. Z. Szultka, H. Lesiński, Poznań 2003. 
Historia Ślaska, t. 1: Do roku 1763, cz. 3: Od końca XVI w. do r. 1763, red. K. Maleczyński, WrocławWarszawa 1963.

Historia Ślaska, t. 2: 1763-1850, cz. 1: 1763-1806, red. W. Długoborski, Wrocław-Warszawa 1966.

Hrabyk P., Granice ziem przemyskiej i lwowskiej (objaśnienie do mapy), „Rocznik Przemyski”, 3, 1913-1922.

Hrabyk P., Ziemia przemyska i litewska (szkic historyczny z mapa), Przemyśl 1921.

Jabłonowski A., Atlas historyczny Rzeczypospolitej Polskiej wydany z zasitkiem Akademii Umiejętności w Krakowie, [t. 1:] Epoka przetomu z wieku XVI-go na XVII-sty, dział 2: „Ziemie Ruskie” Rzeczypospolitej, Warszawa-Wiedeń 1899-1904.

Jakubowski J., Mapa Wielkiego Księstwa Litewskiego w potowie XVI wieku, cz. 1: Część Pótnocna, Kraków 1928.

Jakubowski J., Powiat grodzieński w XVI wieku, „Prace Komisji Atlasu Historycznego", 3, 1935.

Jarmolik W., Powstanie województwa podlaskiego, „Białostocczyzna”, 4 (16), 1989.

Jaszczołt T., Granica pomiędzy ziemiami drohicka i liwska $w$ świetle protokotów komisji z 1546 roku, „Rocznik Liwski”, 6, 2011/2013.

Kalinowski E., Podlasianin Wielkopolaninem? Z nieznanych dziejów przynależności terytorialnej Podlasia po 1569 roku, „Przegląd Historyczny”, 106 (3), 2015.

Kołbuk W., Kościoty wschodnie w Rzeczypospolitej okoto 1772 roku. Struktury organizacyjne, Lublin 1998.

Konopska B., Polskie atlasy historyczne: koncepcje i realizacje, Warszawa 1994.

Kopiczko A., Ustrój i organizacja diecezji warmińskiej w latach 1525-1772, Olsztyn 1993.

Kościót w Polsce, t. 2, red. J. Kłoczowski, Kraków 1969.

Kowalczyk-Heyman E., Dzieje granicy mazowiecko-krzyżackiej (między Drwęca a Pisa), Warszawa 2003.

Kowalczyk-Heyman E., Dzieje granicy mazowiecko-krzyżackiej (między Pisa a Biebrza), Warszawa 2013.

Kowalski M., Księstwa Rzeczypospolitej. Państwo magnackie jako region polityczny, Warszawa 2013.

Kozłowska Z., Mapa historyczna granic politycznych i kościelnych powiatu proszowskiego, „Prace Komisji dla Atlasu Historycznego Polski”, 1, 1922.

Krętosz J., Organizacja archidiecezji lwowskiej obrzadku tacińskiego od XVw. do 1772 roku, Lublin 1986.

Królik L., Organizacja diecezji tuckiej i brzeskiej w XVII i XVIII wieku, Lublin 1983.

Księga pamiątkowa ku uczczeniu dwudziestopięcioletniej dziatalności naukowej prof. Marcelego Handelsmana, Warszawa 1929.

Kumor B., Archidiakonat sadecki. Opracowanie materiatów źródtowych do Atlasu Historycznego Kościota $w$ Polsce, „Archiwa, Biblioteki i Muzea Kościelne”, 8, 1964 .
Kumor B., Dzieje diecezji krakowskiej do roku 1795 , t. 1, Kraków 1998.

Kumor B., Dzieje diecezji krakowskiej do roku 1795, t. 4, Kraków 2002.

Kumor B., Granice metropolii i diecezji polskich 9661939, Lublin 1972.

Kumor B., Prepozytura tarnowska, „Archiwa, Biblioteki i Muzea Kościelne”, 12, 1966.

Kumor B., Rozwój sieci dekanalnej w potudniowej części diecezji krakowskiej do 1772 r., „Roczniki Teologiczno-Kanoniczne”, 25 (1), 1978.

Labuda G., Polska granica zachodnia. Tysiąc lat dziejów politycznych, Poznań 1974.

Litak S., Atlas Kościota tacinskiego w Rzeczypospolitej Obojga Narodów w XVIII wieku, Lublin 2006.

Litak S., Kościót tacinski w Rzeczypospolitej. Struktury administracyjne, Lublin 1996.

Litak S., Struktura terytorialna Kościota tacińskiego w Polsce w 1772 r., Lublin 1980.

Łowmiański H., Rys historyczny województwa nowogródzkiego w jego dzisiejszych granicach (do r. 1795), Wilno 1935.

Maisel W., Znaki graniczne, w: W. Maisel, Archeologia prawna Polski, Warszawa-Poznań 1984.

Małłek J., Granice państwowe, kościelne i administracyjne Prus Ksiązęcych w XVI wieku, „Komunikaty Mazursko-Warmińskie”, 1, 1966.

Manteuffel T., Metoda oznaczania granic w geografii historycznej, w: Ksiega pamiątkowa ku uczczeniu dwudziestopięcioletniej dziatalności naukowej prof. Marcelego Handelsmana, Warszawa 1929.

Mapa województwa krakowskiego z dobry Sejmu Czteroletniego (1788-1792), red. W. Semkowicz, Kraków 1930.

Mazowsze w drugiej potowie XVI w., cz. 2: Komentarz, indeksy, red. W. Pałucki, oprac. A. Dunin-Wąsowiczowa i in., Warszawa 1973 (Atlas historyczny Polski. Mapy szczegółowe XVI wieku, 7).

Michaluk D., Granice województwa podlaskiego i postrzeganie obszaru Podlasia w latach 1513-2013, w: Podlasie nadbużańskie. 500-lecie województwa podlaskiego, red. O. Łatyszonek, Ciechanowiec 2013.

Mietz A., Archidiakonat kamieński archidiecezji gnieźnieńskiej. Struktura terytorialna i stan kościotów w czasach staropolskich 1512-1772, Włocławek 2005.

Mikulski K., Przynależność Inflant do Rzeczypospolitej. Podziaty administracyjne, w: Urzędnicy inflanccy XVI-XVIII wieku. Spisy, oprac. K. Mikulski, A. Rachuba, Kórnik 1994.

Mironowicz A., Biskupstwo turowsko-pińskie w XI-XVI wieku, Białystok 2011.

Mironowicz A., Diecezja biatoruska w XVII i XVIII wieku, Białystok 2008.

Mironowicz A., Diecezja wtodzimierska do końca XVI wieku, Białystok 2013. 
Mironowicz A., Kościót prawostawny dziejach dawnej Rzeczypospolitej, Białystok 2001.

Mucha J., Organizacja diecezji kamienieckiej do roku 1795, „Roczniki Teologiczno-Kanoniczne”, 30 (4), 1983.

Müller W., Diecezje w okresie potrydenckim, w: Kościót $w$ Polsce, t. 2, red. J. Kłoczowski, Kraków 1969.

Müller W., Organizacja terytorialna diecezji ptockiej w XVI-XVIII wieku, „Roczniki Humanistyczne”, 15 (2), 1967.

Müller W., Organizacja terytorialna diecezji przemyskiej w okresie przedrozbiorowym (1375-1772), „Nasza Przeszłość", 46, 1976.

Myśliński K., Geneza i znaczenie powotania województwa lubelskiego w 1474 r., „Rocznik Lubelski”, 16, 1973.

Myśliwski G., Powstanie i rozwój granicy liniowej na Mazowszu (XII - pot. XVI w.), „Kwartalnik Historyczny”, 101 (3), 1994.

Nadolny A., Granice diecezji chetmińskiej, „Studia Pelplińskie", 16, 1985.

Natanson-Leski J., Dzieje granicy wschodniej Rzeczypospolitej, cz. 1: Granica moskiewska w epoce jagiellońskiej, Lwów 1922.

Natanson-Leski J., Epoka Stefana Batorego w dziejach granicy wschodniej Rzeczypospolitej, Warszawa 1930.

Natanson-Leski J., Rozwój terytorialny Polski do roku 1570, Warszawa 1964.

Noga Z., Sprzedaż terytorium siewierskiego biskupowi i kapitule krakowskiej w 1443 roku, „Rocznik Naukowo-Dydaktyczny. Prace Historyczne”, 12, 1987.

Nowacki J., Archidiecezja poznańska w granicach historycznych i jej ustrój, t. 2, Poznań 1964.

Od Kijowa do Rzymu. Z dziejów stosunków Rzeczypospolitej ze Stolica Apostolska i Ukraina, red. M.R. Drozdowski, W. Walczak, K. Wiszowata-Walczak, Białystok 2012.

Pacuski K., Wschodnia granica Mazowsza w średniowieczu w świetle danych historycznych $(X-X V w$.), w: Początki chrześcijaństwa na pograniczu mazowiecko-ruskim w świetle wyników badań wybranych cmentarzysk, red. A. Buko, Warszawa 2019.

Pałucki W., Granice i podziaty polityczno-administracyjne, w: Województwo sandomierskie w drugiej potowie XVI wieku, cz. 2, Komentarze, indeksy, red. W. Pałucki, Warszawa 1993 (Atlas historyczny Polski. Mapy szczegółowe XVI wieku, 2).

Pamiętnik świętokrzyski, Kielce 1931.

Piber-Zbieranowska M., Granice jednostek administracji kościelnej, w: Województwo krakowskie w drugiej potowie XVI wieku, cz. 2: Komentarze, indeksy, red. H. Rutkowski, Warszawa 2008 (Atlas historyczny Polski. Mapy szczegółowe XVI wieku, 1).

Początki chrześcijaństwa na pograniczu mazowiecko-ruskim w świetle wyników badań wybranych cmentarzysk, red. A. Buko, Warszawa 2019.
Podlasie nadbużańskie. 500-lecie województwa podlaskiego, red. O. Łatyszonek, Ciechanowiec 2013.

Polska XVI w. pod względem geograficzno-statystycznym, red. A. Pawiński i in., t. 1-13, Warszawa 18831915 (Źródła Dziejowe, 12-24).

Przyboś K., Granice ziemi lwowskiej (wraz z powiatem żydaczowskim), „Rocznik Przemyski”, 35 (4), 1999.

Przyboś K., Granice ziemi przemyskiej w czasach nowożytnych XVI-XVIII w., „Rocznik Przemyski”, 29-30 (3, 1), 1993-1994.

Przyboś K., Granice ziemi sanockiej w czasach nowożytnych, „Rocznik Przemyski”, 32 (1), 1996.

Rhode G., Die Ostgrenze Polens. Politische Entwicklung, kulturelle Bedeutung und geistige Auswirkung, Bd. 1: Im Mittelalter bis zum Jahre 1401, Köln-Graz 1955.

Rutkowski H., Granica mazowiecko-litewska między Wizna a Grodnem z 1358 r., „Studia Geohistorica", 5, 2017.

Rutkowski H., Granice administracji kościelnej, w: Województwo sieradzkie i województwo tęczyckie w drugiej potowie XVI wieku, cz. 2: Komentarze, indeksy, red. H. Rutkowski, Warszawa 1998.

Rutkowski H., Granice państwowych jednostek terytorialnych, w: Województwo krakowskie w drugiej potowie XVI wieku, cz. 1-2, red. H. Rutkowski, Kraków 2008 (Atlas historyczny Polski. Mapy szczegółowe XVI wieku, 1).

Rutkowski H., Granice państwowych jednostek terytorialnych, w: Województwo sieradzkie i województwo tęczyckie w drugiej potowie XVI wieku, cz. 2: Komentarze, indeksy, red. H. Rutkowski, Warszawa 1998.

Rzepa J., Organizacja terytorialna sądownictwa kościelnego w diecezji krakowskiej do pierwszego rozbioru Polski, „Roczniki Teologiczno-Kanoniczne”, 4 (3), 1957.

Stankowa M., Dawny powiat szczebrzeski. XIVXVIII w., Warszawa 1975.

Stoksik J., Geometrzy matopolscy do końca XVIII wieku. Z dziejów geodezji i kartografii wielkoskalowej w Polsce, Kraków 2013.

Stoksik J., „Zjazdowy sąd komorniczy”: praktyka wytyczania granic przez Sąd Podkomorski, „Krakowski Rocznik Archiwalny”, 17, 2011.

Studia z dziejów Rzeczypospolitej szlacheckiej, red. K. Matwijowski, Z. Wójcik, Wrocław 1968.

Szady B., Geografia struktur religijnych $i$ wyznaniowych w Koronie w II potowie XVIII wieku, Lublin 2010.

Szady B., Granice jednostek administracji kościelnej. B. Diecezje poznańska i wroctawska, w: Wielkopolska w drugiej potowie XVI wieku, red. K. Chłapowski, M. Słoń, Warszawa 2017 (Atlas historyczny Polski. Mapy szczegółowe XVI wieku, 4).

Szymański J., Powstanie archidiakonatu wojnickiego i jego organizacja, „Roczniki Teologiczno-Kanoniczne", 5 (4), 1958.

Ślask w końcu XVIII wieku, cz. 1-2, red. J. Janczak, Wrocław-Warszawa 1984. 
Urzędnicy Wielkiego Księstwa Litewskiego. Spisy, t. 4: Ziemia smoleńska i województwo smoleńskie XV-XVIII w., red. A. Rachuba, oprac. H. Lulewicz, A. Rachuba, P.P. Romaniuk, Warszawa 2003.

Urzędnicy województw kijowskiego i czernihowskiego $X V$-XVIII wieku. Spisy, oprac. E. Janas, W. Kłaczewski, Kórnik 2002.

Urzędnicy wotyńscy XIV-XVII wieku. Spisy, oprac. M. Wolski, Kórnik 2007.

Walczak W., Spór o granice. Przynależność Mozyrowszczyzny do unickiej eparchii turowsko-pinskiej, w: Od Kijowa do Rzymu. Z dziejów stosunków Rzeczypospolitej ze Stolicą Apostolska i Ukraina, red. M.R. Drozdowski, W. Walczak, K. Wiszowata-Walczak, Białystok 2012.

Walczak W., Unicka eparchia turowsko-pinska w XVIIXVII wieku. Struktura organizacyjna, Białystok 2012.

Wielkopolska $w$ drugiej potowie XVI wieku, cz. 1-2, red. K. Chłapowski, M. Słoń, oprac. A. Borek i in., Warszawa 2017 (Atlas historyczny Polski. Mapy szczegółowe XVI wieku, 4).

Wielopolski A., Polsko-pomorskie spory graniczne w latach 1536-1555, „Przegląd Zachodni”, 10, 1954.

Wieteska J., Archidiakonat towicki, Rzym 1966.

Wieteska J., Materiaty do atlasu historycznego Polski w XVIII w. Archidiakonat puttuski w ankiecie Michata Poniatowskiego z r. 1778, „Przegląd Historyczny”, 43 (2), 1952.

Wilkiewicz-Wawrzyńczyk A., Spory graniczne polsko-litewskie w XV-XVII w., „Wiadomości Studium Historii Prawa Litewskiego”, 1, 1938.

Wiśniowski E., Prepozytura wiślicka do schytku XVIII wieku. Materiaty do struktury organizacyjnej, Lublin 1976.

Wojciechowski S., Podziaty administracyjne, w: S. Wojciechowski, Województwo lubelskie w drugiej potowie XVI wieku, Warszawa 1966.

Województwo lubelskie w drugiej potowie XVI wieku, red. W. Pałucki, oprac. S. Wojciechowski, Warszawa
1966 (Atlas historyczny Polski. Mapy szczegółowe XVI wieku, 3).

Województwo ptockie okoto 1578 r., red. S. Herbst, oprac. I. Gieysztorowa i in., Warszawa 1958.

Województwo sandomierskie w drugiej potowie XVI wieku, cz. 1-2, red. W. Pałucki, oprac. K. Chłapowski i in., Warszawa 1993 (Atlas historyczny Polski. Mapy szczegółowe XVI wieku, 2).

Województwo sieradzkie i tęczyckie $w$ drugiej potowie XVI wieku, cz. 1-2, red. H. Rutkowski, oprac. K. Chłapowski i in., Warszawa 1998 (Atlas historyczny Polski. Mapy szczegółowe XVI wieku, 5).

Województwo smolenskie w granicach Rzeczypospolitej 1611 (1618) - 1654 (1667), w: Urzędnicy Wielkiego Księstwa Litewskiego. Spisy, t. 4: Ziemia smoleńska i województwo smolenskie XV-XVIII w. red. A. Rachuba, oprac. H. Lulewicz, A. Rachuba, P.P. Romaniuk, Warszawa 2003.

Wojtkowiak Z., Delimitacja litewsko-kurlandzka z 1584 r., „Lituano-Slavica Posnaniensia”, 3, 1989.

Zajączkowski S.M., O ksztattowaniu się granic dawnych ziem tęczyckiej i sieradzkiej do XVI w., „Slavia Antiqua”, 198, 1971.

Zawadzki W., Oficjalat pomezański w latach 16011821, „Zapiski Historyczne”, 72, 2007.

Zbiór dokumentów matopolskich, cz. 4, wyd. I. Sułkowska-Kurasiowa, S. Kuraś, Wrocław-WarszawaKraków 1969.

Гістарычны атлас Беларусі, т. 1: Беларусь ад старажытныхх часоу да канца XVIII cm., рэА. П. Казанецкі, В. Мікалаевіч, Варшава-Мінск 2008. Крикун М., Адміністративно-територіальний устрій Правобережної Украйни в XV-XVIII cm. Кордони воєводств у світлі джерел, Київ 1993.

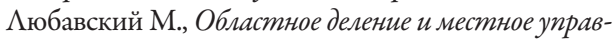
ление Аитовско-русского государства во времени издания первого Аитовского статута, Москва 1892.

Спиридонов М., Закрепощение крестьянства Беларуси (XV-XVI вв.), Минск 1993.

\section{Borders and Administrative Divisions of the Kingdom of Poland and the Polish-Lithuanian Commonwealth, the $15^{\text {th }}-18^{\text {th }}$ Centuries}

\section{Summary}

In this text, the definition of the term border is presented along with a description of differences between public (borders of state and Church divisions) and private borders (those of ownership). Author depicts the process of borders shaping, methods and basis for drawing borders on the map, basic changes of state borders, the evolution of names of state administrative divisions. Also the matters regarding to border disputes and ways of settling them, by borders commissions or delimitations, are mentioned, as well as changes in the organisation of the borders' structures. Those refers to the administrative divisions of the state (palatinates, judicial and fiscal districts, private district, precincts of the judicial starost's jurisdiction), of the Catholic Church, and the Eastern Churches (metropolis', dioceses, archdeaconries, deaneries, protopopies, 
parishes, oficjalats, special units like Warmia and the Duchy of Siewierz). The issue of drawing borders on historical maps was the main research problem in the second half of the $19^{\text {th }}$ century, when the idea to prepare a "Historical Atlas of Poland" was put forward. The author of the article synthesised the history of that idea, together with discussions on methods and ways of its realisation and the publication based on it. At the end of the text, the issue of borders of ownership (borders of land domain) are presented along with description of delineating them, techniques of marking borders in the field and measures of settling the border disputes. An appendix with the state administrative division of the Polish-Lithuanian Commonwealth after the year 1569 is added at the end of the article. The present text was originally written as a chapter of planned academic textbook entitled Historical geography of Poland to the end of the $18^{\text {th }}$ century and it is more like a lecture than a publication depicting all discussions amongst scholars about the topic. Originally, there had been only a bibliography without footnotes in the text. As the book did not got published, footnotes were added as a reference to the most important publications on the subject in question.

dr hab. Krzysztof Chłapowski - emerytowany profesor Instytutu Historii im. Tadeusza Manteuffla PAN, pracownik Zakładu Atlasu Historycznego IH PAN w latach 1969-2016, od 2001 do 2013 r. przewodniczący Komisji Geografii Historycznej KNH

(kkchlapowski@gmail.com)

Krzysztof Chłapowski, Dr. hab. - Professor Emeritus in The Tadeusz Manteuffel Institute of History, Polish Academy of Sciences; in 1969-2016 employed at the Department of the Historical Atlas; in 2001-2013 President of the Commission for Historical Geography at the Committee on Historical Sciences

(kkchlapowski@gmail.com) 